\title{
COSIMO ROSSELLI'S BIRMINGHAM ALTARPIECE, THE VALLOMBROSAN ABBEY OF S. TRINITA IN FLORENCE AND ITS GIANFIGLIAZZI CHAPEL
}

\author{
Susan J. May and George T. Noszlopy*
}

ABSTRACT: The subject of the present study is Cosimo Rosselli's The Adoration of the Child Jesus (c. 1485), today in the collection of the Barber Institute of Fine Arts, University of Birmingham. It takes as its starting point two factors noted from the Barber Institute guide - the 'complex subject matter' and the painting's unknown original location. The paper thus falls into two sections. Part 1 consists of a fresh iconographical analysis of the altarpiece grounded in accepted historical and contextual scholarship. This section underscores Rosselli's indebtedness to his contemporaries, showing however that he was immediately responsive to the latest conceptual innovations taking place around him and that he was himself capable of a degree of novelty. Part 2 addresses the question of the site for which Rosselli's altarpiece may have been made. As is the case with the overwhelming majority of extant works of art, an extensive search notwithstanding, no contractual document or early description of the altarpiece in situ has so far come to light. A detailed hypothesis is, nonetheless, put forward, which proposes the identity of the patronal family and the chapel for which the painting may have been

* This article results from collaborative research with my late husband, Prof. George T. Noszlopy (d. 5 June 2011), Birmingham City University, whose keen observations and expertise set the project in motion. This paper is dedicated to his memory. Sincere thanks go to David Hemsoll, Adrian Hicken, Ugo Silli, Paul Spencer-Longhurst, Nick Stanley, Zsuzsa Urbach, Robert Wenley, Carolinne White and the editor and anonymous readers of this Journal. Financial assistance was generously afforded by Birmingham City University, the research brought to a conclusion thanks to a Small Research Grant from the British Academy. Any mistakes are my own.

Abbreviations and conventions:

$\mathrm{ASF}=$ Florence, Archivio di Stato

$\mathrm{ABSM}=$ Florence, Archivio dei Buonomini di San Martino

$\mathrm{BCNF}=$ Florence, Biblioteca Centrale Nazionale

All dates are cited in the new style unless otherwise noted. 
commissioned. Thorough research into family history, topographical information and circumstantial particulars renders the hypothesis entirely plausible. It should be reiterated that no documentary evidence directly supporting the patron and position put forward here has been uncovered to date. By the same token, nothing has so far been found that negates the possibility. The findings of this research are therefore set before the scholarly community for their value, and/or potential, as contributions to knowledge about the iconography, date and context of the altarpiece. The paper shows, in short, that Cosimo Rosselli's Adoration of the Child Jesus is to be understood as a contemplation on the mystery of the incarnation and that it was probably painted in, or very shortly after, 1485. It makes a case for the altarpiece having been commissioned by the Gianfigliazzi clan of Florence for its family chapel in the abbey church of Santa Trinita.

$* * * * *$

The composition of Cosimo Rosselli's Adoration of the Child Jesus (Fig. 1), in the Barber Institute of Fine Arts in Birmingham, ${ }^{1}$ revolves around the Virgin Mary

1. Cosimo Rosselli's Adoration of the Child Jesus (inv. 65.7) was acquired by the Barber Institute in 1965. The provenance of the painting can be documented no further back than c. 1848 , when it was purchased by John Rushout, second Baron of Northwick (1769-1859); Worcester, County Record Office, 'Northwick Papers', 705:66, 4221, box 9 (unnumbered papers). Then attributed to Domenico Ghirlandaio, it was hung at Thirlestane House in Cheltenham. On the baron's dying intestate in 1859, the altarpiece was auctioned through Phillips and purchased by George Rushout, third Baron of Northwick; see $A$ Catalogue of the Late Lord Northwick's Extensive and Magnificent Collection of Ancient and Modern Pictures ..., London 1859, p. 5 (as Ghirlandaio); and the letter of 17 Feb. 1993 from P. SpencerLonghurst, Curator, Barber Institute, on the Institute's curatorial file. It was moved to Rushout's seat at Northwick Park and remained there, passing through various owners, until the death of Captain Edward George Spencer-Churchill in 1965, when it was offered to the Barber Institute; see E. Gabrielli, Cosimo Rosselli, London and Turin 2007, pp. 212-14; on the Northwick Park-Thirlestane House Collection see O. Bradbury and N. Penny, 'The Picture Collecting of Lord Northwick', Burlington Magazine, CxLIV, 2002, pp. 485-96 (Part I) and 606-17 (Part II). The painting was still listed as a Ghirlandaio in Phillips, $A$ Catalogue of the Pictures, Works of Art, \&c. at Northwick Park, London 1864, repr. 1908, pp. 38, 44. Subsequently T. Borenius and L. Cust, Catalogue of the Collection of Pictures at Northwick Park, London 1921, pp. 38-39, assigned it to School of Verrocchio; then R. van Marle, Development of the Italian Schools of Painting, 19 vols, The Hague 1931, XIII, p. 341, gave it to Piero di Cosimo. For the 
kneeling in adoration of the infant Christ, who is propped on a loose bundle of straw on the ground. They are joined by a circle of holy persons from various historical periods: in clockwise order from the top, these can be identified as St Francis, the three Magi, St Benedict and St Jerome. In the golden heavens above, surrounded by red-winged seraphim, God the Father makes the sign of benediction with his right hand, while pointing with his left to his son below. Immediately beneath the Father, on a vertical axis with the Child, hovers the foreshortened dove of the Holy Spirit, an angel to either side. At the extreme right in the middle-ground is the now partially cutoff figure of Joseph. This hieratic, that is to say non-narrative, arrangement is set on a grassy, flower-bedecked knoll in a landscape receding to a glowing horizon.

The altarpiece has attracted scant scholarly attention, a neglect which may be accounted for in part by Giorgio Vasari's assessment of Rosselli as 'not a very rare or excellent painter'. ${ }^{2}$ Any such perception, however, overlooks his considerable reputation and prolific output by the mid 1480 s, particularly since his participation in the Sistine Chapel mural decoration (1481-82), as well as his importance as an exemplar to other local artists. ${ }^{3}$ His clients ranged from the magnate and merchant élite, to abbots and priests, to artisan confraternities, down to small shopkeepers. ${ }^{4}$

attribution to Cosimo Rosselli, which is uncontested, see B. Berenson, Italian Pictures of the Renaissance: Florentine School, 2 vols, London 1963, I, p. 191.

2. G. Vasari, Le vite de ' più eccellenti pittori, scultori e architettori ..., ed. G. Milanesi, 6 vols, Florence 1878, III, pp. 183-93 (183): 'Il qual Cosimo, sebbene non fu nel suo tempo molto raro ed eccellente pittore, furono nondimeno l'opere sue ragionevoli'. Many scholars appear to have followed Vasari. For example, Rosselli has been criticised for disproportionate anatomical drawing, schematic rendition of drapery and stiff, dry linearity; see A. Padoa Rizzo, 'La Cappella Salutati nel Duomo di Fiesole e l'attività giovanile del Cosimo Rosselli', Antichità Viva, XVI, 1977, pp. 3-12; W. Griswold, 'A Drawing by Cosimo Rosselli', Burlington Magazine, CXXIX, 1987, pp. 514-16; P. Nuttall, 'The Life and Times of Cosimo Rosselli', in Cosimo Rosselli, ed. Blumenthal (as above), pp. 11-22 (14). For a milder assessment of some of his late works see Nuttall, ibid., pp. 13, 17; and D. A. Covi, 'A Documented Altarpiece by Cosimo Rosselli', Art Bulletin, LIII, 1971, pp. 236-38; they acknowledge in his late style a softer handling, more convincing falls of cloth, livelier poses and pictorial tonality, noting the cumulative influence on the artist of Alesso Baldovinetti, the Pollaiuolo brothers, Andrea del Verrocchio, Botticelli, Ghirlandaio, Filippino Lippo and Perugino.

3. See Gabrielli (as in n. 1), p. 63; for extant frescoes by Rosselli at S. Ambrogio and SS. Annunziata see ibid., pp. 147-49, 185-94; for S. Ambrogio see also below, n. 54. See also the various contributions to Cosimo Rosselli, Painter of the Sistine Chapel (exhib. cat.), ed. A. R. Blumenthal, Winter Park, FL 2001; as well as A. Thomas, 'The Workshop as Space of Collaborative Artistic Production', in 
The present study takes as its starting points three aspects of Rosselli's Birmingham altarpiece which, so far, have eluded satisfactory investigation. The first is its intriguing iconography, with its unusually complex subject matter, including references to Christ's birth and death, the Holy Trinity and the Adoration of the Magi. The second and third are its unknown original location and the question of who may have commissioned it. ${ }^{5}$ The paper thus falls into three sections. Part I consists of a fresh iconographical analysis of the altarpiece and argues that it is to be understood as a contemplation on the mystery of the Incarnation. Part II addresses the question of the site for which Rosselli's painting may have been made. It makes a case for the altarpiece having been commissioned around 1485 by the Gianfigliazzi family of Florence, for its family chapel in the abbey church of S. Trinita. Finally Part III focusses on the particular members of the Gianfigliazzi family who, as we suggest, instigated and negotiated the commission.

Part I: The Painting and its Iconography

Rosselli's Adoration of the Child Jesus differs today from its appearance in the fifteenth century. Reports in the Barber Institute's curatorial file show that the two vertical, outer boards of the altarpiece have been cut down and the entire bottom edge

Renaissance Florence: A Social History, ed. R. J. Crum and J. T. Paoletti, Cambridge and New York 2006, pp. 415-30 (423; e.g., Thomas notes there that Rosselli's work was represented in the duomo in Florence, in the form of a pair of gilt candlesticks).

4. For references see above, n. 3. Regarding his wealthier clients, notably Rosselli was paid for unspecified work in the palace of Filippo di Vieri di Niccolo de' Medici, Archbishop of Pisa, in 1466; see V. Budny and F. Dabell, 'Hard at Work "di notte chome di di”: A Close Reading of Cosimo Rosselli's Career, With Some New Documents', in Cosimo Rosselli, ed. Blumenthal (as in n. 3), pp. 23-43 (29), who also observe that Rosselli family names echo those of the Medici; ibid., p. 36. These facts, not to mention Rosselli's painting of the Adoration of the Magi probably for the Compagnia dei' Magi at S. Marco (Galleria degli Uffizi inv. 1890 494; Gabrielli, as in n. 1, pp. 155-57), do not seem to bear out the assertion of M. O'Malley, 'Finding Fame: Painting and the Making of Careers in Renaissance Italy', Renaissance Studies, XXIV, 2010, pp. 9-32 (31), that Rosselli 'was rarely hired by patrons in the Medici circle or in the major Florentine convents'.

5. Both these factors are highlighted in the Barber Institute's guidebook; see R. Verdi, The Barber Institute of Fine Arts, London 2005, p. 32. Regarding the tiny 'Annunciation to the shepherds' on the hillside to the left, the present analysis argues that this is a misreading of the iconography. 
of the panel trimmed, the latter as a result of severe woodworm damage. ${ }^{6}$ Thus in its original form the figure of Joseph would not have been so severely sliced through; and the robes of the two foremost figures would have appeared in their entirety.

The balance of evidence on Rosselli's surviving oeuvre indicates that throughout his career his altarpieces were usually accompanied by predella panels, the execution of which was often delegated to a collaborator. ${ }^{7}$ This arrangement is also found in other Italian altarpieces of the period; typically, the predella scenes were hagiographical in nature, related to figures in the main composition. ${ }^{8}$ Rosselli's Adoration was, therefore, probably supported on a predella too. The central predella panel was most likely a Crucifixion, thus completing the component parts of the Trinity and fulfilling Christ's sacrifice foretold in the main panel. ${ }^{9}$ The frame was probably wooden, decorated with gilt grotesques and the family crest of its patron. ${ }^{10}$

The introduction of the Trinitarian theme into the traditional pictorial type of the Adoration of the Child became well established during Rosselli's lifetime. This period

6. During restoration in 2000, a cradle, considered to have been fitted in England in around 1900-20 and which was causing damage to the panel, was removed, as was a cross-grain addition along the panel's bottom edge, where the worst woodworm damage had occurred. Two vertical wooden strips $12 \mathrm{~mm}$. wide which had been added to each side were left in place. All of these additions were thought to have been made as part of the same campaign. Barber Institute curatorial file, 'Treatment Report', July 2000, pp. 68; see also the 1998 'Condition Report'.

7. Gabrielli (as in n. 1), pp. 99-100, 179-81, 231-33, 234-36.

8. S. Nethersole, Devotion by Design: Italian Altarpieces before 1500, London 2011, p. 125.

9. Pietro Orioli's altarpiece The Nativity with Saints, c. 1485-95, now in London, National Gallery, inv. 1849.1-2, is an example where the central predella panel is a Crucifixion, vertically aligned with the Christ Child, who is recumbent on the ground and being adored by his kneeling Mother, and God the Father directly above; illustrated on the National Gallery website and in Nethersole (as in n. 8), fig. 26, p. 24. We are indebted to David Hemsoll for this observation.

10. The practical work of constructing the frame and panels may have been carried out by Giuliano da Maiano, who was responsible for the construction of Rosselli's 'St Barbara' altarpiece (painted 1468-69). Da Maiano had made many such frames over the years for the workshop of Neri di Bicci, to whom Rosselli was apprenticed until 1456. See P. Nuttall, “La tavele Sinte Barberen”: New Documents for Cosimo Rosselli and Giuliano da Maiano', Burlington Magazine, CXXVII, 1985, pp. 367-72 (368, 371); for Rosselli's apprenticeship see below at n. 55. The proposed date of the altarpiece, to be addressed below, probably places it slightly too early for the sort of carved stone all'antica arch that was to become popular in Florence in the late 15th century. On marble frames see M. Callahan and D. Cooper, 'Set in Stone: Monumental Altar Frames in Renaissance Florence', Renaissance Studies, XxIV, 2010, pp. 33-55 (34-35). 
saw the exchange of several theological treatises on the topic, both before and after the Council of Florence in 1439, at which the Trinity was the main point of discourse; reflections on the triune Godhead even filtered down into vernacular poetry. ${ }^{11}$ Rosselli's altarpiece combines this newer, Trinitarian iconography with the older type of the Virgin humbly adoring her son, naked and prostrate before her. Such depictions had developed out of narrative images of the Nativity which can be traced back as far as the Dijon altarpiece by the Master of Flémalle: its composition was inspired by the Revelations of St Bridget of Sweden (1303-73), who had a vision of the Christ Child lying not in a manger but on the ground, before his kneeling mother. ${ }^{12}$ This type, the Bridgettine Virgin, was adopted and adapted from the early 1450s by Filippo Lippi, who painted several Adoration scenes in which the Virgin and Child are removed from the customary stable and placed in a mountain wilderness. In Lippi's Adoration of the Infant Jesus commissioned in the late 1450s for the new chapel of the Palazzo Medici, all that remains of the traditional Nativity is the position of the Virgin and Child (Fig. 2). ${ }^{13}$ This is no longer a narrative representation of the birth of Christ. The flying angels normally hovering above the stable are replaced by God the Father and the dove of the Holy Spirit, the complete Trinity here emphasising that the Christ Child is to be understood as God incarnate. ${ }^{14}$ Lippi's Adoration was in turn a prototype for Andrea della Robbia's large terracotta relief of the Adoration of the Child (c. 1479-80) in the Brizi chapel of the chiesa maggiore at La Verna, the mountain on which St Francis is reputed to have received the stigmata. Here the meaning is made explicit by the inscription in the predella: 'The Word is made flesh from the Virgin Mary' (Fig. 3). ${ }^{15}$ The image clarifies the apparent oxymoron of the Virgin birth: the inclusion of God the Father and the Holy Ghost emphasises the

11. D. V. Kent, Cosimo de 'Medici and the Florentine Renaissance, New Haven, CT and London 2000, pp. $138,325$.

12. Dijon, Musée des Beaux-Arts, inv. 150. See The Master of Flémalle and Rogier van der Weyden, ed. S. Kemperdick and J. Sande, Ostfildern 2009, pp. 202-05.

13. J. Ruda, Fra Filippo Lippi: Life and Work with a Complete Catalogue, London 1993, pp. 224-30 (ill. p. 225).

14. Ibid., p. 224.

15. 'VERbum CARo FATTUM [sic] EST DE VIRGINE M[ARI]A'; J. Pope-Hennessy, 'Thoughts on Andrea della Robbia', Apollo, CIX, 1978, pp. 176-97 (176); Ruda (as in n. 13), p. 228. 
incarnation of the former by grace of the latter-God the Father made flesh through the grace of the Holy Spirit and the spotless, mortal vessel of Mary.

Rosselli, too, took up this new type of Adoration iconography, even adopting in the Birmingham altarpiece Lippi's motif of looping part of Mary's mantle over her wrist. ${ }^{16}$ Although clearly influenced by the older artist, however, Rosselli did not adopt for his own painting Lippi's forbidding, rocky scenery, presenting instead an expansive, lush landscape between verdant coulisses (cf. Fig. 2). His planting of the sacred figures into an open landscape has been compared with a work by Lippi's son Filippino, whose Virgin and Child with Sts Jerome and Dominic (Fig. 4), of c. 1485, also shows the Virgin Mary with her hair enveloped in a transparent veil. ${ }^{17}$ This comparison is certainly suggestive, even if Rosselli probably also studied verdant vistas in Netherlandish paintings, which were both plentiful and much admired in Italy. ${ }^{18}$ In fact, there are numerous indications of borrowings in his altarpiece, suggesting that Rosselli was both attuned to and animated by contemporary Florentine artistic activity, with its pronounced use of symbolic references and its characteristic experimentation in composition and representation of space. ${ }^{19}$ The motif of the Christ Child with a bundle of wheat, symbolic of the bread of the Eucharist and foreshadowing his sacrifice, was commonly adopted following the arrival in Florence

16. A. Thomas, 'The Workshop as Space of Collaborative Artistic Production', in Renaissance Florence: A Social History, ed. R. J. Crum and J. T. Paoletti, Cambridge and New York 2006, pp. 415-30 (422), suggests that Rosselli may have been involved in the early stages of the Medici chapel project, having travelled back from Rome with Benozzo Gozzoli in 1458. In the Camaldoli Adoration, which is attributed to Lippi and loosely copies his Palazzo Medici Adoration, the motif is used for both sides of the Virgin's mantle; see Ruda (as in n. 13), pp. 230-33 (ill. p. 232).

17. For the date of 1485 see J. Dunkerton, Giotto to Dürer: Early Renaissance Painting in the National Gallery, New Haven, CT and London 1991, pp. 338-39. Filippino Lippi’s altarpiece (London, National Gallery, NG 293) was commissioned by a member of the Rucellai family for the St Jerome chapel in the Vallombrosan house of S. Pancrazio, Florence.

18. P. Nuttall, From Flanders to Florence: The Impact of Netherlandish Painting 1400-1500, New Haven, CT and London 2004, pp. 124-27. A possible iconographic motivation for the rural landscape in this painting is suggested below at $\mathrm{nn} .120-122$.

19. On the artistic environment in Florence at this time see the discussion of Leonardo's Adoration of the Magi in R. Hatfield, Botticelli's Uffizi 'Adoration': A Study in Pictorial Content, Princeton, NJ 1976, p. 113. 
of Hugo van der Goes' Portinari altarpiece in May $1483 .{ }^{20}$ Rosselli's columbine or aquilegia (centre foreground) may well be a quotation from the still life in the main panel of the same work, the Adoration of the Shepherds. ${ }^{21}$ The columbine was at once a symbol of the dove of the Holy Ghost and of the innocence of the Virgin Mary. ${ }^{22}$ The flower symbolism continues with the maidenhair fern and dog violets which pepper the grassy knoll symbolising respectively the humility of the Virgin and the incarnation of Christ. ${ }^{23}$

As for compositional elements, it has been argued in the literature on Rosselli's altarpiece that the triangle formed by the Virgin and the two foremost Magi, overlaid onto the elliptical foreground, is probably indebted to Leonardo da Vinci's studiously worked-out composition for the Adoration of the Magi, in which a pyramid sits comfortably within a semi-circle (Fig. 5). ${ }^{24}$ Commissioned in 1481 for S. Donato a Scopeto in Florence, but left incomplete when Leonardo departed for Milan the following year, his unfinished painting nonetheless remained on the high altar until $1496 .{ }^{25}$

By comparison with the works by Lippi and Leonardo, Rosselli had many more principal figures to accommodate in his composition. His arrangement of the holy figures has affinities with altarpieces depicting a so-called sacra conversazione, in which saints are grouped in a credible, unified space around the centralised Virgin and Child in a single panel; though he chooses a rural, not an architectural setting. ${ }^{26}$ To enable all the adoring figures to gaze on the holy infant, and at the same time ensure

20. Nuttall, Flanders to Florence (as in n. 18), p. 133. The Portinari altarpiece stood in the church of S. Egidio, which served as chapel for the Compagnia di S. Luca, to which Rosselli belonged; Budny and Dabell (as in n. 4), p. 28.

21. See B. W. Meijer, Firenze e gli antichi Paesi Bassi 1430-1530: dialoghi tra artisti, Florence 2008, pp. 68-69.

22. M. Levi d'Ancona, The Garden of the Renaissance: Botanical Symbolism in Italian Painting, Florence 1977, pp. 105-08.

23. Ibid., pp. 133-34 and 398-401 respectively.

24. Gabrielli (as in n. 1), p. 214.

25. M. Kemp, Leonardo da Vinci: The Marvellous Works of Nature and Man, London 1981, pp. 66-78.

26. For literature on and examples of altarpieces depicting a so-called sacra conversazione, usually within an architectural setting, see J. Burckhardt, The Altarpiece in Renaissance Italy, ed. and tr. P. Humfrey, Oxford 1988, pp. 66-125. Rosselli's first known commission was for a sacra conversazione altarpiece for S. Trinita; see below at n. 59 . 
that their faces are sufficiently visible to the viewer, he has tilted up the foreground, to present the scene as if on the slope of a grassy hummock. The disposition of the landscape thus allows the Virgin and her holy companions to join in a ring to adore the Child in their midst, onlookers of the altarpiece effectively completing the circle. The arc circumscribing the upper edge of the knoll passes behind St Jerome, the Virgin and St Francis, thus virtually obliterating the middle ground, the scene passing rapidly from foreground to background. Then, beyond the arc of the up-tilted flowery hummock on which the Adoration takes place, the landscape changes abruptly to a typically Quattrocentesque scene of hills, rocks, water and trees, receding to a palebluish horizon.

Despite their coherent arrangement in space, the holy figures selected for representation in this altarpiece come, as has been noted above, from different periods in history. Of the three saints in the middle ground, the earliest is one of the four Latin Fathers of the Church, St Jerome (342-420), shown here as an ascetic beating his bared breast with a stone to fend off hallucinations, recalling his four years living as a hermit in the Syrian desert. As Jerome wrote in a letter to his disciple Eustochium (Epistle 22):

The Lord himself is my witness, after many tears I fixed my eyes on heaven and seemed to find myself among the angelic hosts. ${ }^{27}$

Part of Jerome's vivid, detailed description of the punishments he inflicted upon himself to banish temptations of the flesh is quoted by Jacobus de Voragine in the Golden Legend:

All the company I had was scorpions and wild beasts, yet at times I felt myself surrounded by clusters of pretty girls, and the fires of lust were lighted in my frozen body and moribund flesh. So it was that I wept continually and starved the rebellious flesh for weeks at a time. Often I joined day to night and did not stop beating my breast until the Lord restored my peace of mind. ${ }^{28}$

27. St Jerome, Lettres, ed. J. Labourt, 8 vols, Paris 1949-63, I, pp. 117-18 (Epistle 22.7): ‘... ut mihi ipse testis est Dominus, post multas lacrimas, post caelo oculos inhaerentes nonnumquam videbar mihi interesse agminibus angelorum.'

28. Jacobus de Voragine, Legenda aurea, ed. G. P. Maggioni, 2 vols, Tavarnuzze 1998, pp. 1004-05: 'Et cum scorpionum tantum essem socius et ferarum, sepe choris intereram puellarum et in frigido corpore et carne premortua sola libidinum incendia pullulabant. Itaque continue flebam et repugnantem carnem hebdomadarum inedia subigebam. Diem crebro coniunxi cum nocte nec prius pectoris cessabam verberibus quam a domino rediret tranquillitas.' The English version of this text is cited from Jacobus de 
Jerome's frank account was repeated and elaborated on in the Regula monacharum, an anonymous late thirteenth- or early fourteenth-century pseudograph which was very widely diffused. ${ }^{29}$ This added to his purported visions 'the Trinity itself, which I saw, I know not with what kind of sight'. ${ }^{30}$ In view of the Trinitarian theme within Rosselli's altarpiece, it seems quite probable that St Jerome was included at least partly with Pseudo-Jerome's vision of the Trinity in mind. Moreover, there was a thriving cult of St Jerome in Florence. The Congregazione degli eremiti di $S$. Girolamo relocated to the city in 1413 , having expanded following its formation in Fiesole eight years earlier. ${ }^{31}$ Holy relics of St Jerome were amongst those donated to Florence at the time of the Council there in $1439,{ }^{32}$ which helps to explain the swelling of his popularity in the city through the rest of the century. The Florentine diarist Luca Landucci records the occasion when, on the saint's feast day in 1487, his relics were at last placed in a new reliquary, ${ }^{33}$ which was subsequently processed annually around the city:

And on 30 September 1487, the relics of St Jerome, that is to say a lower jaw and a bone from the arm, were taken out from the altar of the cross of S. Maria del Fiore, and were laid in silver and gold, very rich and at much expense. A beautiful procession was made, and [it was] placed in the said chapel with great devotion. And this was done at his own expense by the laudable messer Jacopo Manegli, canon in the said church. And it is said he had spent 500 florins of gold, and more than this, endowing a chapel. And every year this beautiful relic is processed devoutly. ${ }^{34}$

Voragine, The Golden Legend: Readings on the Saints, tr. W. Granger Ryan, 2 vols, Princeton N.J. 1993, II, p. 213.

29. E. Rice, 'Saint Jerome's "Vision of the Trinity": An Iconographical Note', Burlington Magazine, CXXV, 1983, pp. 151-55. Of the many surviving manuscripts of the Regula monacharum, Rice cites two which were certainly in Florence and nearby Fiesole in the 15th century (ibid., n. 9): Florence, Biblioteca Medicea Laurenziana MSS Plut. XIX.9, and Fesul. 27.

30. Ibid., p. 152. Pseudo-Jerome, Regula monacharum, 26 (Patrologiae cursus completus. Series latina, ed. J.-P. Migne, Paris 1844-64, xxx, col. 414): 'Testis est ipsa Trinitas quam cernebam, nescio quo intuitu.'

31. B. Ridderbos, Saint and Symbol: Images of Saint Jerome in Early Italian Art, tr. P. de WaardDekking, Groningen 1984, pp. 75, 77.

32. A. Cocchi, Les anciens reliquaires de Santa Maria del Fiore et de San Giovanni de Florence, Florence 1903, p. 13.

33. For a description see ibid., pp. 35-37.

34. Luca Landucci, Diario fiorentino dal 1450 al 1516, continuata da un anonimo fino al 1532, ed. I. Del Badia, Florence 1883, repr. 1985, p. 51: 'E a dì 30 di settembre 1487, si trasse le reliquie di San Girolamo, cioè una mascella e un osso del braccio, dell'altare della croce di Santa Maria del Fiore, e 
That the assembled saints in Rosselli's Adoration are intended to be understood as contemplating the mystery of the Incarnation, rather than the Nativity, is subtly indicated within the iconography, through two scenes placed in the background behind St Jerome. Just over his right shoulder, a bush crackles with orange flames, giving off plumes of billowing smoke (Fig. 7). The blazing shrubbery alludes to the miracle of the Burning Bush, in which the angel of the Lord appeared to Moses. Medieval typology paralleled the Burning Bush, which was not consumed by the flames (Exodus 3.2), with the Virgin who conceived by the Holy Ghost but without being tainted by flushes of carnal desire. ${ }^{35}$ The allegory is represented prominently in the central panel of Nicolas Froment's famous altarpiece in Aix-en-Provence. The Virgin and Child are shown within the bush, seated, unperturbed amidst branches licked all around by leaping tongues of fire (Fig. 6). ${ }^{36}$ Beneath the bush, an annunciation is taking place: Froment depicts an angel together with a male figure who has been variously interpreted as Moses, Joachim, or Joseph. ${ }^{37}$ Whoever he may be intended as, commentators agree that Froment's work alludes to the Annunciation and refers to a miraculous conception (whether by Joachim's wife Anna or by the Virgin Mary).

furono legate in ariento e oro, molto riccamente, con grande spesa. E fecesi una bella processione, e posta in detta Cappella molto divotamente. E questo fece di sua proprio spesa el laldabile messer Iacopo Manegli, canonico in detta Chiesa. E dissesi, aveva speso 500 fiorini d'oro, e oltre a questo, dotato una Cappella. E ogn'anno va quella bella reliquia a processione divotamente.'

35. The analogy of the Burning Bush as a symbol of Mary's virginity is called upon frequently in literature from the Church Fathers onwards, in hymns and in the visual arts. See E. Harris, 'Mary in the Burning Bush: Nicolas Froment's Triptych at Aix-en-Provence', Journal of the Warburg Institute, I, 1938, pp. 281-86 (281); C. I. Minott, ‘A Note on Nicolas Froment's “Burning-Bush” Triptych', this Journal, XXv, 1962, pp. 323-25; M. Levi D'Ancona, The Iconography of the Immaculate Conception in the Middle Ages and Early Renaissance, New York 1957, pp. 68-69.

36. Inscriptions above and (partially visible here) below the panel function as aids to the reading of the symbolism; see Harris (as in n. 35), p. 282.

37. For the first reading see Harris, ibid., pp. 283-84, who argues that the composition as a whole alludes to the Annunciation through the device of the angel together with other aspects of the iconography. She observes, however (p. 284 n. 2), that Pierre-Joseph de Haitze, Les Curiosités les plus remarquables de la ville d'Aix, Aix-en-Provence 1679, p. 151, identified the male figure as Joachim; while not supporting this in her own interpretation, Harris comments that an additional allusion to the birth of the Virgin Mary (the Immaculate Conception) might have appealed to René of Anjou, who commissioned the altarpiece. This point is further discussed by Minott (as in n. 35), who identifies the figure as Joseph, p. 324. 
Rosselli also combines the Burning Bush with an Annunciation, discernable on the hill directly behind it (Fig. 7). The descending angel, flying down from right to left, is silhouetted against the strip of sky. Among a flock of white and black sheep, or sheep and goats, three human figures can be made out: a reclining figure outlined against the green hillside is propped on one arm, while raising the other to his eyes as he notices the approaching angel; above him, two smaller figures skip towards each other on the horizon, seemingly oblivious to the unfolding drama. To date this motif has been interpreted as an Annunciation of the Nativity to the three shepherds. ${ }^{38}$ It is proposed here, however, that Rosselli's reference is to the apocryphal annunciation to Joachim. This related that an angel appeared to Joachim when he was with his shepherds, telling him that his wife Anne, who had hitherto been barren, was now with child; that child would grow up to be the Virgin Mary. The story was well known through two main sources, both widely circulated (and in fact related). One of these was the Protevangelium of Ps.-James; the other, the Liber de nativitate S. Mariae, was believed to have been written by St Jerome, behind whom Rosselli's scene is placed. ${ }^{39}$ The annunciation to Joachim was represented by several fourteenth- and fifteenthcentury artists. ${ }^{40}$ In Giotto's fresco of the episode in the Arena Chapel in Padua, Joachim is shown asleep, the visitation occurring in his dream, but as in Rosselli's painting, he is depicted on a hillside with his white sheep and black goats, ${ }^{41}$ accompanied by two shepherds (Fig. 8). If our interpretation of Rosselli's tiny scene is correct, then his detail refers to the Immaculate Conception, putting into visual form

38. Verdi (as in n. 5), p. 32.

39. Libri de nativitate mariae, 2 vols, Turnhout 1997 (Corpus Christianorum, Series Apocryphorum, IX-X), II, pp. 282-85 (Liber de nativitate S. Mariae, 2.4-3.3, with French translation). The work was clearly attributed to St Jerome in one of its prologues; see ibid., pp. 272-73, and the introduction by R. Beyers, pp. 7-8. Jacobus da Voragine also named Jerome as its author. In his version of the annunciation episode, however, Joachim was alone when the angel appeared to him; see Legenda aurea (as in n. 28), II, pp. 903-04; tr. Granger Ryan, II, p. 151-02.

40. The Annunciation to Joachim was painted in fresco, c. 1335, by Taddeo Gaddi in the Baroncelli Chapel in S. Croce, Florence; also by Benozzo Gozzoli, 1491, now in Castelfiorentino, Biblioteca Comunale. See too the small panel from a polyptych on the Life of the Virgin by Bartolo di Fredi, Annunciation to Joachim, c. 1383, now in the Vatican, Pinacoteca.

41. On the symbolism of the white sheep and black goats in depictions of this episode see Levi D'Ancona, Iconography of the Immaculate Conception (as in n. 35), p. 68. 
the doctrine of the divine Word made flesh, rather than a narrative episode from the Nativity of Christ. ${ }^{42}$

The saint depicted at the far left of the painting, hands clasped in prayer, can be identified by his simple attributes of black habit, tonsure and long, grey beard as St Benedict (c. 480-547). Founder of the oldest, western order, whose rule became the basis of monastic law, it will be argued further below in Part II that his inclusion is likely related not only to the chapel for which, as we believe, the altarpiece was painted, but also to the church in which it is located. ${ }^{43}$

Opposite St Jerome is St Francis of Assisi (c. 1181-1226). He holds a slender, polylobate golden cross in his right hand, a reference to the apparition he experienced while in retreat on Mount Alverna, while displaying with his left hand the stigmata he received on the same occasion. ${ }^{44}$ Again, his significance for the proposed site of the altarpiece will be discussed further below.

The three Magi, all depicted with saintly haloes, are visually linked together by their striking red garments. They are identifiable as the wise men by the use of familiar tropes: they represent three different ages; Balthazar (middle right) has a Moorish appearance; all three carry gifts in their hands; and a doffed crown is placed on the ground behind the youngest Magus (foreground left), visible just below his extended arm. ${ }^{45}$ Through pose and gesture, the wise men clearly recognise the divinity of Christ. The altarpiece is not meant to represent the narrative moment of Epiphany

42. It may be noted, finally, that St Jerome was seen as connected with the Immaculate Conception also on account of a passage in his Breviarum in Psalmos, on Psalm 77; see Levi D'Ancona, Iconography of the Immaculate Conception (as in n. 35), p. 70 n. 163; see also ibid., p. 55, where she notes the references to the Immaculate Conception in Signorelli's Virgin and Child Enthroned with Saints of 1519-22, commissioned by the Confraternity of St Jerome in Arezzo, in which the saint figures prominently.

43. G. Kaftal, Iconography of the Saints in Tuscan Painting, Florence 1952, cols 145-74, 'St. Benedict'. St Benedict's vision of the Holy Trinity is pictured in Francesco d'Antonio's predella panel in Bourges Museum; ibid., col. 164 and fig. 178. Levi D'Ancona, Iconography of the Immaculate Conception (as in n. 35), p. 42, notes that the Benedictine order was the first to promote the cult of the Immaculate Conception.

44. Jacobus de Voragine (as in n. 28), II, p. 1023; tr. Granger Ryan, II, p. 224. According to his biographer Thomas of Celano, the apparition was like a crucified seraph. Life cycles of St Francis typically show the seraphic vision or a vision of Christ on the cross.

45. The Magi are identified with the kings of Psalm 72.10, one of the liturgical readings for Epiphany; G. Schiller, Iconography of Christian Art, tr. J. Seligman, 2 vols, London 1971, I, p. 95. 
as told in the gospel of Matthew (2.1-2), but the Epiphany did carry particular resonance for Florence, sharing the date of its feast, on 6 January, with that of the baptism of Christ by St John the Baptist, the city's principal patron saint. Moreover, both feasts shared the same liturgical theme - the revelation of Christ's divinity. ${ }^{46}$ Due to the promotion of the Compagnia de' Magi by Cosimo il Vecchio de' Medici and the propagation of the cult by subsequent generations of the family, the Magi, in a process of gradual osmosis, had become associated with them. ${ }^{47}$ In the chapel of the Medici palace, the Procession of the Magi was celebrated in Benozzo Gozzoli's frescoes. Under Lorenzo de' Medici, the family continued to self-fashion itself in public. $^{48}$ Other families appear to have avoided ostentatious display so as not to be seen to be rivalling Medici ascendancy; or they could borrow its glory, as when patrons used the iconography of the Magi to gesture homage to the Medici regime. ${ }^{49}$

Finally, at the extreme right of Rosselli's Adoration can be seen the now cutthrough half-figure of Joseph, who frequently in his paintings of this type appears very close to the edge of the panel, often twisting, as here, to lead the ox and ass, using a rope over his shoulder.

On the basis of the foregoing analysis, some remarks can be made about dating. Firstly, if, as suggested above and as seems probable, the altarpiece is indebted compositionally to Leonardo's Adoration of the Magi (Fig. 5), then Rosselli's design has a terminus post quem of 1482 (that is, the date at which Leonardo stopped work on his commission for S. Donato a Scopeto). ${ }^{50}$ Our other considerations, however, point to a somewhat later date. The prominent floral symbolism of the aquilegia in the foreground of Rosselli's painting suggests its execution after the arrival in Florence of

46. Ibid., I, pp. 94-113.

47. R. Hatfield, 'The Compagnia de' Magi', this Journal, XXXIII, 1970, pp. 107-61.

48. K. Lowe, 'Lorenzo's "Presence" at Churches, Convents, and Shrines in and Outside Florence', in Lorenzo the Magnificent: Culture and Politics, ed. M. Mallett and N. Mann, London 1996, pp. 23-36.

49. Guasparre Dal Lama's commissioning of Botticelli's Adoration of the Magi is a case in point; see J. M. A. Najemy, A History of Florence 1200-1575, Chichester 2008, p. 331. Kent (as in n. 11), p. 305, asserts that most of the Florentine Magi images of the mid-15th century which were not commissioned by the Medici were commissioned by their friends, apparently in tribute to them.

50. See above at n. 25 . 
the Portinari altarpiece, which occurred in May $1483 .{ }^{51}$ It can also be noted that Rosselli's early dry, stiff, linear style has by this time softened, so that the Virgin has the gently falling drapery, fuller lips and air of wistful piety of his later phase. ${ }^{52}$ Finally, if Rosselli drew inspiration from Filippino Lippi's Virgin and Child with Sts Jerome and Dominic (Fig. 4) then his painting dates to c. 1485 or slightly afterwards. ${ }^{53}$ He would thus have worked on it concurrently with his commissions for the Cappella del Miracolo del Sacramento in the church of S. Ambrogio, which he carried out between May 1484 and August 1486. ${ }^{54}$

\section{Part II: A Proposed Site}

Cosimo Rosselli learned his trade in the thriving Florentine workshop of Neri di Bicci, from a date prior to March 1453 (the start of Neri's account book) until $1456 .{ }^{55}$ As his assistant, Rosselli was involved in Neri's commissions for the Vallombrosan abbey church of S. Trinita, most notably in 1455 for the Spini family chapel, ${ }^{56}$ as well as Neri's fresco decoration in the same year in the neighbouring Vallombrosan church of S. Pancrazio ${ }^{57}$ In the years following his apprenticeship, Rosselli, as a former pupil of Neri, established a reputation for himself in Florence among the rising merchant classes, both as an industrious and reliable painter and as a devout man. ${ }^{58}$

51. See above at n. 20.

52. Nuttall, 'Life and Times of Cosimo Rosselli' (as in n. 3), p. 17. See also D. A. Covi, 'A Documented Altarpiece by Cosimo Rosselli', Art Bulletin, LIII, 1971, pp. 236-38 (237), where he comments on Rosselli's treatment of landscape and use of tonality in his late works.

53. Cf. Gabrielli (as in n. 1), p. 214, who favours a date between Aug. 1486 and 1490.

54. For these works in fresco see E. Borsook, 'Cults and Imagery at Sant'Ambrogio in Florence', Mitteilungen des Kunsthistorischen Institutes in Florenz, XXv, 1981, pp. 147-202 (176).

55. Budny and Dabell (as in n. 4), pp. 23-24.

56. Neri di Bicci, Le Ricordanze 10 marzo 1453-24 aprile 1475, ed. B. Santi, Pisa 1976, pp. 25-26; A. Thomas, 'Neri di Bicci's Assumption of the Virgin for Santa Trinita, Florence: Squaring the pyramid', Apollo, CXLVI, 1997, pp. 42-51.

57. Budny and Dabell (as in n. 4), p. 27. Neri's St Giovanni Gualberto and Saints of the Vallombrosan Order, considered to be his finest work, has since been moved from the cloister of S. Pancrazio to the Compagni Chapel in S. Trinita.

58. Budny and Dabell (as in n. 4), p. 28; A. Padoa Rizzo, 'Cosimo and Bernardo Rosselli's Work for Lay Confraternities', in Cosimo Rosselli, ed. Blumenthal (as in n. 3), pp. 61-73 (61, 71). 
It has been plausibly suggested that Rosselli's first known independent commission, a sacra conversazione altarpiece for the Scali family chapel in S. Trinita (1460), was linked in some way to his connection with Neri, whose own association with the abbey church was very well established. ${ }^{59}$ Much later, in the 1490s, Rosselli was called upon to paint a Road to Calvary panel for the chapel of the Madonna dello Spasimo in S. Trinita. ${ }^{60}$ Whether in the intervening years he undertook other projects for the abbey church is not documented, but the recurrent link with S. Trinita makes it a point of departure in seeking the original location of his Birmingham altarpiece with its clear Trinitarian references. ${ }^{61}$

The Spini and Scali, along with other local families who patronised S. Trinita at that time, like the Davanzati and Ardinghelli, belonged to the new merchant élite; the church was also supported by older, powerful Florentine households such as the Gianfigliazzi, Compagni, Bartolini and Sercialli (see Fig. 9). ${ }^{62}$ In line with developments in the city's other churches during the Quattrocento, the wealthy patrons of S. Trinita were busily re-decorating their chapels. The Bartolini chapel benefitted from a new fresco cycle and Lorenzo Monaco's Annunciation (c. 1420-25); ${ }^{63}$ the Spini chapel was fully redecorated and adorned with Neri di Bicci's impressively large Assumption of the Virgin (1455-56) ${ }^{64}$ Rosselli's sacra conversazione for the Scali chapel (1460) replaced an altarpiece of only twenty-three years earlier. ${ }^{65}$ In 1464 , Bongianni di Bongianni Gianfigliazzi was granted rights over the cappella maggiore of S. Trinita, allowing himself, his sons and his male heirs to be interred there and to

59. Thomas, 'The Workshop' (as in n. 3), pp. 418-21, draws attention to the long working relationship with S. Trinita of Neri's workshop, continuing that of his father, Bicci di Lorenzo; in 1458 Neri moved his working premises to be near to the abbey church. On Rosselli's Scali commission see Budny and Dabell (as in n. 4), pp. 27-28; Padoa Rizzo (as in n. 3), p. 6; Gabrielli (as in n. 1), p. 29.

60. Padoa Rizzo, ibid., p. 71; W. and E. Paatz, Die Kirchen von Florenz: ein Kunstgeschichtliches Handbuch, 6 vols, Frankfurt 1952-55, v, p. 372 n. 282.

61. It may be germane to note that the workshop of Bernardo di Stefano Rosselli, Cosimo Rosselli's cousin, was on the corner of Via Porta Rossa opposite S. Trinita. Cosimo's own bottega was in the Piazza di S. Maria in Campo. See Budny and Dabell (as in n. 4), pp. 33-37.

62. R. N. Vasaturo, 'S. Trinita nelle vicende fiorentine: straldi di storia', in La chiesa di Santa Trinita a Firenze, ed. G. Marchini and E. Micheletti, Florence 1987, pp. 1-6 (3).

63. M. Eisenberg, Lorenzo Monaco, Princeton, NJ 1989, pp. 128-36.

64. See above, n. 56.

65. See n. 59. 
display the Gianfigliazzi coat of arms, with the obligation to decorate and endow the chapel. ${ }^{66}$ Alesso Baldovinetti was commissioned to design a stained glass window, to paint the vault and walls in fresco and to provide a large high altarpiece of the Trinity (completed in 1472) ${ }^{67}$ Not to be outdone, Francesco Sassetti's refurbishment of his family's chapel was crowned with Domenico Ghirlandaio's Adoration of the Shepherds in $1485{ }^{68}$ Through such patronage S. Trinita became a notable representative of the vogue which had existed in Florence since the 1430s for single panel altarpieces with multiple holy figures sharing a convincing, unified space.

An important chapel at S. Trinita for which, so far, nothing is known of any fifteenth- or sixteenth-century refurbishment, is the one long held by the Gianfigliazzi family. ${ }^{69}$ Dedicated to St Benedict, this was situated at the east end of the north aisle:

66. ASF, Not. antecos. 5046 (Pierozzo di Cerbino), insert 3, fol. $71^{\mathrm{r}-\mathrm{v}}$. We shall return to Bongianni di Bongianni below (p. =note90 and passim).

67. The altarpiece, now in the Accademia (inv. 8637), was installed in 1472, replacing Cimabue's Madonna and Child Enthroned with Angels (Galleria degli Uffizi, inv. 1890 8343). For the many contemporary portraits in the frescoes, including members of the Medici, see Vasari (as in n. 2), II, p. 594; also H. Horne, 'A Newly Discovered "Libro di Ricordi” of Alesso Baldovinetti', Parts I and II, Burlington Magazine, II, 1903, pp. 22-32 and 167-74.

68. J. K. Cadogan, Domenico Ghirlandaio, Artist and Artisan, New Haven, CT and London 2000, pp. 253-55.

69. An inventory of 22 Mar. 1484 describes Gianfigliazzi liturgical objects stored in the sacristy but is mute on the content of the St Benedict chapel; ASF, Conv. soppr. 89, no. 75, transcribed in La chiesa di Santa Trinita (as in n. 62), pp. 389-90 (appx 3). A sepoltuario dated 1614 records only tomb monuments: 'Capella ultima di questa nave a canto la Porta, che risponde in su la Piazza della famiglia de Gianfigliazzi con Archa di Marmo, e monumenti no. dua del la stessa famiglia et arme nel Archo, e fuora nella strada similmente de Gianfigliazzi. Intitolata In San Benedetto'; ASF, Manoscritti, 628, 'Sepoltuari', fol. 973. By the time Averardo Niccolini and Benigno Davanzati wrote their histories of S. Trinita in 1661 and 1740 respectively, the St Benedict chapel had been subjected to the pietra serena architectural interventions of 1630, still in place today. Don Averardo details Vincenzo Gianfigliazzi's 1630 refurbishment, but no mention is made of the chapel's previous appearance or contents; see ASF, Conv. soppr. 89, 135, 'Libro cartaceo scritto circa la metà del secolo XVII da D. Averardo Niccolini Abate di S. Trinita contenente notizie ...'; and Florence, Fondo S. Trinita, 'Istoria della venerabile Basilica della SSma. Trinita di Firenze: Opera del Padre D. Benigno Davanzati di Firenze Monaco Vollombrosano et Abate di detto Luogo, L'anno 1740', pp. 214-15. Similarly, while there is mention of Vincenzo's activity in the 'Giornale della fabrica di S. Trinita segnato C, 1604-1629', this does not extend to noting the removal of an incumbent altarpiece; ASF, Conv. soppr. 89, 2, fols $1^{\mathrm{r}}-62^{\mathrm{v}}$. The 1630 chapel refurbishment 
passing through the entrance into the church, it is the first chapel on the right (see Fig. 9). ${ }^{70}$ Notwithstanding the lacuna in the historical records, a plausible case has been made by Carl Brendon Strehlke arguing that Cenni di Francesco's Coronation of the Virgin and Saints (Fig. 11), completed in the 1390s, still stood in the Gianfigliazzi chapel throughout the fifteenth century. ${ }^{71}$ If his proposition is correct, however, then the polyptych format of Cenni's altarpiece, with its trecentesque style, its gothic arches, crockets and finials, and its liberally stamped and gilded surfaces, would have rendered it obviously outmoded amongst its fifteenth-century counterparts in the other chapels. In what follows, we shall argue that in fact, the Gianfigliazzi did adorn their chapel with a new altarpiece; and that the commission, for an Adoration of the Child Jesus, went to Cosimo Rosselli. ${ }^{72}$

The traditional territory of the Gianfigliazzi family was in the gonfalone unicorno of S. Maria Novella, ${ }^{73}$ more specifically, however, their lineage was concentrated in a solid block shared with the church and abbey of S. Trinita, circumscribed by the

is most fully explained by C. B. Strehlke, 'Cenni di Francesco, the Gianfigliazzi and the Church of Santa Trinita in Florence', J. Paul Getty Museum Journal, xx, 1992, pp. 11-40 (15-16).

70. On this chapel see R. N. Vasaturo, 'Appunti d'archio sulla construzione e trasformazioni dell'edificio', in La chiesa di Santa Trinita (as in n. 62), pp. 7-22 (10); Paatz (as in n. 60), v, p. 355.

71. Strehlke (as in n. 69); for the iconography of the altarpiece see pp. 23-29.

72. While we have been unable to uncover evidence which definitively locates the altarpiece in the St Benedict chapel, neither have we found any which invalidates the possibility, either by placing Rosselli's painting elsewhere, or by recording an alternative altarpiece in the chapel. Documentary evidence has been sought in both the Gianfigliazzi family archive and in extant church records held in the ASF. The former is held in ABSM 4.1 and 4.2; most of these documents, however, pertain to the line of Bongianni di Bongianni and, as will be seen, they are not particularly helpful for the present enquiry. ABSM MS 2.1.0.1, Bongianni's Libro di ricordi, details his personal patronage from 1464 of the cappella maggiore (fols $11^{\mathrm{v}}, 24^{\mathrm{v}}$ ) but contains no apparent reference to Gianfigliazzi family patronage of the St Benedict chapel. Likewise the documents within ABSM 4.1.1, 'Contratti e testamenti 1340-1738', do not appear to make reference by name to Cosimo Rosselli, to any painter or to an altarpiece. State and church records pertaining to S. Trinita are fragmentary, due partly to the vicissitudes of the Vallombrosan order. They are summarised by A. Guidotti, 'Fonti d'archivio per la storia artistica di S. Trinita: Cenni sull'antico patrimonio librario del monastero', in La chiesa di Santa Trinita (as in n. 62), pp. 325-39. Early guides to Florence and its churches, monasteries and convents have likewise yielded nothing that might relate to Rosselli's Birmingham altarpiece.

73. For the earliest mention of the family's residence there, in 1288, see Giovanni Villani, Nuova cronica, ed. G. Porta, 3 vols, Parma 1990-91, I, p. 593. 
Piazza S. Trinita, the Lungarno, Via Parione and Via Parioncino (Fig. 10). ${ }^{74}$ Living so close to the church, it is no surprise that the family had since January 1365 (January 1366 new style) enjoyed patronage rights to a chapel at S. Trinita; indeed, the Gianfigliazzi had a close relationship with both the abbey and the Vallombrosan order which ministered there. ${ }^{75}$ The church housed a large number of Gianfigliazzi tombs and the chapel was used by a number of different lines of the family. ${ }^{76}$ The wealthiest branch by far was represented in the fifteenth century by the household headed by Giannozzo di Stoldo (Fig. 12). ${ }^{77}$ From 1430 Giannozzo donated annual sums for the provision of mass in the Gianfigliazzi family's St Benedict chapel on the feast day of St Francis. ${ }^{78}$ These seem to have been upheld by Gianozzo's heirs until at least $1485 .{ }^{79}$

The most prominent (though less wealthy) line of the family in the first quarter of the century was headed by Messer Rinaldo Gianfigliazzi (1335-1425), who lived in the palazzo next door to S. Trinita (Figs 10,14). During Rinaldo's patriarchy, he and his eldest son Giovanni served terms as operaio to S. Trinita, Rinaldo's personal devotion to the Vallombrosan order evidenced by the fact that he was buried in the church wearing its habit. ${ }^{80}$ Following his death, three of Rinaldo's sons-Giovanni, Francesco and Jacopo-continued to live in the Gianfigliazzi palace with their wives

74. In the 1427 catasto, 18 separate properties within this block were owned by the Gianfigliazzi, with 48 out of the city's 58 family members living here; K. J. F. Murphy, 'Piazza Santa Trinita in Florence 1427-1498', Ph.D. thesis, Courtauld Institute of Art 1997, p. 102.

75. Two family members had been Master General of the Vallombrosan order: for Don Niccolò Gianfigliazzi (1316-20) see P. Lugano, L'Italia benedetta, Rome 1929, p. 371; for Don Bernardo Gianfigliazzi (1400-22) see F. F. Tarani, L'Ordine vallombrasano: Note storico-cronologiche, Florence 1920, p. 114

76. BCNF MS Poligrafico Gargagni 949-50 (Gianfigliazzi), passim.

77. In the 1427 Catasto, his taxable assets were valued at F. 14,002, the greatest of the family; Murphy (as in n. 74), p. 98, citing ASF, Catasto, 75 , fol. $417^{\mathrm{r}}$.

78. ASF, Catasto, 813 , fol. $77^{\mathrm{r}}$.

79. In 1447, 'Gli eredi di Giannozzo Gianfigliazzi detto fare ogni anno inperpetua la festa di San Francesco': ASF, Corporazioni religiose soppresse dal governo francese (hereafter Conv. soppr.) 89, 75, 'Libro della Sagrestia di S. Trinita Segnato A', fol. $24^{\mathrm{r}}$. At the bottom of the same page, 'Piero di Giannozzo a fatto la festa ogni anno ... Alluj ... 31 marzo 1485'. For other references to the feast of St Francis in the chapel of St Benedict see ibid., fol. $33^{\text {r-v }}$.

80. Murphy (as in n. 74), p. 228. 
and families. ${ }^{81}$ This line of the family had been very active in communal politics in the late-fourteenth and early-fifteenth centuries on behalf of the ruling, oligarchic, antiMedici party, for which reason, with the return of the Medici in 1434, Giovanni, Francesco and his son Baldassare, and Jacopo, were all banished into exile. ${ }^{82}$ Cosimo de' Medici il Vecchio was in the habit, if his adversaries proved in any way elusive, of dishonouring them by having them painted as if hung by their feet in a state of nature on the façade of the Podestal palace (imagini infamanti); such was the fate in 1440 of Baldassare di Francesco. ${ }^{83}$ We may surmise from this, and his wife Tommasa's appeal to the commune for financial aid, that Baldassare had died in exile. ${ }^{84}$ In her tax return of 1457, Tommasa declared that she was being supported by the Benedictine nuns of the Badia. She added rather sharply that she had previously requested cash assistance from the 'ufficiali de rubelli', but had been told that 'there are no more goods to be distributed to those known to be heirs of Rinaldo Gianfigliazzi and that all the said goods have already been allocated for other dowries' ${ }^{85}$ The fact that Tommasa made a

81. According to the catasto of 1427 (ASF, Catasto, 75, fol. 141 ${ }^{\mathrm{r}}$ ), Jacopo's tax return of 1430 (ASF, Catasto, 363, fol. $21^{\mathrm{r}}$ ) and that of Giovanni and Francesco (ASF, Catasto, 362, fol. 684 $4^{\mathrm{r}}$ ); Murphy (as in n. 74), pp. 97 n. $48,103-04$ n. 75.

82. Benedetto Dei (1418-92), La cronica dall'anno 1400 all'anno 1500, ed. R. Barducci, Florence 1984, p. 53; B. Preyer, 'Around and in the Gianfigliazzi Palace in Florence: Developments on Lungarno Corsini in the Fifteenth and Sixteenth Centuries', Mitteilungen des Kunsthistorischen Institutes in Florenz, XLVIII, 2004, pp. 55-104 (61). The main Gianfigliazzi opposition to the Medici thus disabled through banishment, the loyalty of other members of the family was signalled by the customary means of marriage, as in the case of Giannozzo Gianfigliazzi, who married Cosimo's cousin Averardo's daughter; Najemy (as in n. 49), p. 268.

83. 'Eorum figuris et pitturis ad naturale detraendis', Act of Condemnation, 6 and I3 July 1440, Commiss. Rin., iii. 667, cited by F. T. Perrens, The History of Florence under the Domination of Cosimo, Piero, Lorenzo de' Medicis, 1434-1492, tr. H. Lynch, 3 vols, London 1892, I, p. 34. For the genre of imagini infamante see S. Y. Edgerton, Pictures and Punishment: Art and Criminal Prosecution during the Florentine Renaissance, Ithaca 1985.

84. Baldassare had married his distant relative Tommasa di Piero di Stoldo Gianfigliazzi in 1433 (see Fig. 13); BCNF MS Passerini, 156, insert 8, fol. $1^{\mathrm{v}}$. Their union is noted with a date of 1432 in BCNF MS Poligrafico Gargagni 949-50 (Gianfigliazzi), 57, suggesting that the marriage was prior to 25 Mar. 1433 (new style).

85. '... non cera più beni a stribuire che sapartenessino a rede di messer Rinaldo Gianfigliazzi e che tutti detti beni erano casegnati per alter dote'; Murphy (as in n. 74), p. 106 n. 88, citing ASF, Catasto, 813, fol. $78^{\mathrm{r}}\left[1^{\mathrm{r}}\right]$. 
point of mentioning this earlier rejection implies that she felt it unfair: not only had she been robbed of a husband, exiled after one or two years' marriage, but she was also refused subsequent charity from the government responsible for that loss.

Tommasa was a Gianfigliazzi in her own right, having grown up just around the corner on the Lungarno, in a property owned by her grandfather Giannozzo di Stoldo. ${ }^{86}$ Unlike her late husband's, her branch of the family were staunch Medici partisans. ${ }^{87}$ Eventually in 1467 , the old 'palazzo di messer Rinaldo' was ceded by the Ufficiali della Torre to Tommasa in payment of her dowry. ${ }^{88}$ Following this, a confusing picture regarding ownership of the palace ensues until 1469, when the Ufficiali sold it to another member of the Gianfigliazzi family, who in turn apportioned it and sold parts on, the main part to Tommasa, who was installed in the piano nobile. ${ }^{89}$

It is probably no coincidence that Bongianni di Bongianni Gianfigliazzi (141884), the individual who had purchased the 'old' palace, did so in the year of Lorenzo il Magnifico's ascendancy. A Gianfigliazzi family member from a different line (see Fig. 12), Bongianni emerged as a major political figure and a man of increasing wealth

86. Murphy (as in n. 74), p. 98, citing ASF, Catasto, 75, fol. $141^{\mathrm{r}}$. For Giannozzo di Stoldo see above at n. 77. The 1427 Catasto places Tommasa in a property owned by her grandfather Giannozzo on the corner of Lungarno and Via Parioncino; Murphy (as in n. 74), p. 285 and fig. 11.

87. For the pro-Medici allegiance of Tommasa's uncle Giannozzo di Stoldo see D. V. Kent, The Rise of the Medici: Faction in Florence 1426-1434, Oxford and New York 1978, p. 353.

88. Murphy (as in n. 74), p. 106, citing ASF, Not. antecos. 21062 (Nastagio Vespucci), insert 7, under date.

89. According to Murphy (as in n. 74), p. 106, though unreferenced and unexplained, in 1468 Tommasa renounced her rights to the palace. In 1469 the Ufficiali della Torre sold it to Bongianni Gianfigliazzi, who, in a document of 5 Dec. 1469, sold a large part to Tommasa and a smaller section to another Gianfigliazzi relative, Bertoldo. Bongianni retained one bay, which gave him access through to his own 15th-century palace on the Lungarno (see Fig. 10); Preyer (as in n. 71), pp. 61-62, citing ASF, Catasto, 917, fol. 160, and ASF, Not. antecos, 21064 (Nastagio Vespucci), insert 4, fol. 204. This division of the old palace is recorded by Bongianni Gianfigliazzi in his Libro di ricordi in ABSM MS 2.1.0.1, fol. 18v 'El resto di detto palagio si chonsenti e nominai nella chonpera mona Tommasa, donna fu di Baldassarre di Francescho di messer Rinaldo Gianfigliazzi, per una parte cioè per f. 700, e Bertoldo di Bertoldo Gianfigliazzi per una altra parte per f. 500, chome tutto apare per la diviza in detta charta'. Still in 1469 the palace was termed '...vulgariter nuncipato il palazzo di Messer Rinaldo Gianfigliazzi'; ABSM MS 4.1.1.0.2, 'Contratti della casa Gianfigliazzi', insert 4, 'Dal 1469 al 1480', first document dated 3 Jan. 1469 , fol. $1^{\mathrm{r}}$. 
and influence during the middle years of the fifteenth century. ${ }^{90} \mathrm{He}$ played a prominent role as diplomat and adviser to Lorenzo de' Medici; for example, as one of numerous critical ambassadorial missions, Bongianni accompanied Lorenzo in 1471 when he travelled to Rome to congratulate the newly-elected Pope Sixtus IV. In 1480 he was in Rome again, among those who petitioned the pope (with success) for the liberation of Florence from the interdict of $1478 .{ }^{91}$ For most of his life Bongianni, along with his brother Gherardo (1403-63), was accustomed to making devotions in the Gianfigliazzi chapel of St Benedict in S. Trinita. ${ }^{92}$ This changed, however, from February 1464 when, as already mentioned above, Bongianni was granted rights over the church's cappella maggiore..$^{93}$ Gherardo having recently died, Bongianni had him buried there and, as executor, diverted Gherardo's provision for the St Benedict chapel to the main altar chapel. ${ }^{94}$ Meanwhile detailed provision was made in Bongianni's will to finance masses and other divine offices in perpetuity after his death. Most conspicuous, of course, was the major redecoration project for the capella maggiore on which he now embarked. ${ }^{95}$

From 1464 the St Benedict chapel was thus left without the benefit of Bongianni's endowments. The diversion of his patronage to the cappella maggiore must have been felt keenly in the Gianfigliazzi chapel, even if other individuals from various branches of the family continued to provide for it. ${ }^{96}$ As we have seen, the wealthiest of these

90. In 1470 Bongianni was awarded the highest honour of the republic, the arms "cavaliere "a spon d'oro"'; see his Libro di ricordi in ABSM MS 2.1.0.1, fol. 12 $2^{\mathrm{v}}$. The oration on that occasion, to a congregation of 5,000 in the duomo, declared that Bongianni ' $\mathrm{fu}$ fatto sindacho e prochuratore a ffare tale atto per parte del popolo el magnificho giovane Lorenzo di Piero di Chosimo'; ibid. See V. Arrighi, 'Gianfigliazzi, Bongianni [1418-1484]', in Dizionario biografico degli Italiani, LIX, Rome 2000, pp. 344-47; V. Arrighi and F. Klein, 'Da mercante avventuriero a confidente dello Stato: profile di Bongianni Gianfigliazzi attraverso le sue ricordanze', Archivio storico italiano, CLXI, 2003, pp. 53-79.

91. See Arrighi and Klein (as in n. 90), esp. pp. 53, 60, 63 and n. 34.

92. For example, until 1464 Bongianni paid for the feast of St Laurence to be celebrated in the chapel of St Benedict; Davanzati, 'Istoria' (as in n. 69), p. 214.

93. See above at n. 66.

94. ASF, Not. antecos. 21063 (Nastagio Vespucci), insert 4, fols 55-58. This was in accordance with the wishes of Gherardo's widow, Lena; ASF, Conv. soppr. 89, 47, fol. 44 ${ }^{\mathrm{r}}$; Conv. soppr. 89, 75, fol. $31^{\mathrm{r}}$.

95. See above at n. 67.

96. For endowments from Piero di Ruberto Gianfigliazzi in the early 1470s see ASF, Conv. soppr., 89, 75, fols $24^{\mathrm{r}}$ (27 Feb. 1471) and $32^{\mathrm{r}-\mathrm{v}}$ (18 Mar. 1473). Much later, following the death of one Bartolomeo 
was the line of Giannozzo di Stoldo Gianfigliazzi, which paid for the annual celebration at the chapel of the feast day of St Francis. ${ }^{97}$ In view of the high standing of Giannozzo and his heirs, it may be supposed that the Franciscan celebrations were well funded; but they can hardly be compared with the decorative projects taking place at other chapels at S. Trinita. Furthermore, the old altarpiece by Cenni di Francesco (Fig. 11), presumed to have still been in place at that time, must have been seen by Giannozzo's heirs as in need of replacement, not least since St Francis is absent from the saints depicted on it. ${ }^{98}$

In light of these findings, a commission leading to Rosselli's Adoration (Fig. 1) may be seen, at least hypothetically, as a feasible solution to the needs of the chapel and the family members who bore the burden of maintaining it. Any new altarpiece would necessarily incorporate St Benedict, to whom the chapel was dedicated; in addition, if such a painting were commissioned by the Giannozzo heirs, we would also expect to see St Francis. Both these saints are present in Rosselli's painting, while the iconography of the three Magi, with its cultural identification of the cult of the Magi with the presiding family, would at the same time have represented implicit reassurance of family compliance with the Medici regime. The Gianfigliazzi family's familiarity with Rosselli's paintings, together with his popularity across social strata, would have made this artist an unsurprising choice for any such commission. ${ }^{99}$ As for the subject of the work, paintings of the adoration of Christ by the Virgin Mary had become extremely popular in Florence during the third quarter of the fifteenth

Gianfigliazzi (1419-93), his widow endowed the chapel with altar furnishings, liturgical vestments and a line of flags bearing the Gianfigliazzi crest; additionally she continued to observe there her deceased husband's feast day of St Bartholomew; records for 1493, 1494 and 1497 in ASF, Conv. soppr., 89, 75, fol. $44^{\mathrm{r}}$. In the same year, at least six Gianfigliazzi households were donating funds to the church for prayers for the deceased: the houses are listed under street name with the amounts of donations in 1493, 'tutte le case et Annime di questo popolo di Santa Trinita'; ASF, Conv. soppr., 89, 75, fol. $47^{\mathrm{r}}$.

97. See above, nn. 78-79. Conversely, however, it seems that the feast of St Laurence was no longer celebrated there from 1464; see above at n. 92.

98. On Cenni's altarpiece see above, n. 71.

99. See above, nn. 3-4; for the Scali altarpiece already in S. Trinita see n. 59. 
century. ${ }^{100}$ The choice of a Bridgettine adoration expressly evoking the Trinity can be seen as appropriate given the dedication of S. Trinita. ${ }^{101}$

Moreover, and as will be demonstrated next, further aspects of the painting's iconography coincide closely with the concerns of the abbey of S. Trinita. It is useful to begin this part of our enquiry by briefly, and of course hypothetically, considering the nature of any discussions which might have taken place between the Gianfigliazzi and the abbot of S. Trinita about a proposed new altarpiece for the St Benedict chapel. Looking back at Rosselli's previous work in the same church, we have the contract of 1460 for his Scali altarpiece. If this might be considered a precedent for the hypothesised contract with the Gianfigliazzi, then the cost of making an altarpiece for the St Benedict chapel may have been divided equally between the family and the abbot, acting on behalf of the church and the order. ${ }^{102}$ In this eventuality — which must remain conjectural - it would be expected that the abbot would have had some influence over the iconography of the painting, to reflect Vallombrosan tenets. The abbot would almost certainly have endorsed a subject reflecting the particular devotions inculcated by the order's founder, St Giovanni Gualberto (c. 995-1073, canonised 1193), which were still assiduously practised in the fifteenth century, as they are today. These comprised special dedication to, above all, the Holy Trinity; to the Madonna; and to the miraculous Holy Cross which completed the process of Giovanni Gualberto's conversion. ${ }^{103}$

100. Pope-Hennessy (as in n. 15), p. 176; Ruda (as in n. 13), p. 221.

101. As observed above at n. 9, the Trinitarian references were probably augmented in the predella to the altarpiece.

102. Such was the case with the Scali commission. The notarised agreement dated 11 Febr. 1460 (new style) with Monna Costanza Scali is recorded in a note made by Don Bartolomeo di Giovanni, abbot of S. Trinita; ASF, Conv. soppr., 89, 75, fol. $7^{\mathrm{r}}$. See Budny and Dabell (as in n. 4), pp. 27-28. Between 1479 and 1485, the abbot of S. Trinita was Don Matteo d'Antonio Lapini da San Gaudenzio, then from 1485 to 1497, the abbot was Don Arrigo di Sagramone Bonbeni da Firenze; Giuseppe Richa, Notizie istoriche delle chiese fiorentine, divise ne'suoi quartieri, 10 vols, Florence 1754-62, III, p. 179.

103. D. F. Tarani, 'Ufficiatura e devozioni particolari in S. Trinita', in Nel VII centenario della sagra di S. Trinita di Firenze, 1227-1927, Florence 1927, pp. 30-33 (31-32). This slim volume is on the shelves of the Kunsthistorisches Institut in Florenz, shelfmark L960 'media', although it is not listed on the catalogue. For the order's devotion to the Holy Cross see S. Casini, Storia di S. Giovanni Gualberto Fiorentino, Rome 1927, pp. 53-67. The cross is one of Gualberto's attributes; A. Padoa Rizzo, 
To better convey the context for which we propose that Rosselli's painting was commissioned, it is germane at this point to summarise Giovanni Gualberto's significance. A member of the Florentine noble Visdomini family, he entered the Benedictine order as a monk at S. Miniato al Monte. Disillusioned by the corruption which he witnessed in the church, he left S. Miniato in search of a more austere and contemplative congregation following the strict observance of St Benedict or the even older eastern rule of St Basil. Unable to find an adequately penitential house, tradition holds that the location for the setting up of his new order was indicated to him by God when a spring burst forth at his feet in a beautiful, shady valley on the slope of Monte Secchieta, about twenty miles east of Florence. The miraculous spring became an important feature in his hagiography. The silence and restfulness of the spot, among the crags, streams and chestnut trees, reminded Giovanni Gualberto of descriptions of the ancient Thebaid, the chosen land of the early monks in the Nile valley. ${ }^{104}$ His new order, taking the name of Vallombrosa, would follow the austere rule of St Benedict, the severity of which he further increased. ${ }^{105}$ Inspired by this community, other Vallombrosan houses soon opened and the order expanded considerably in the years following its founder's death. ${ }^{106}$ In keeping with the Vallombrosan themes of penitence and austerity, not only St Benedict but also St Jerome, as an ascetic in the desert, often appears in the iconography of the order. St Jerome and St Francis of

Iconografia di San Giovanni Gualberto. La pittura in Toscana, Vallombrosa 2002; Kaftal (as in n. 43), cols 569-80, 'St. John Gualbert'.

104. Casini (as in n. 103), p. 65: 'Pareva la silenziosa valle creata apposta per la meditazione, come la Tebaide antico o la Nitria, destinate a racogliere nel pensiero di Dio.' See also ibid., pp. 66-67: 'Venerabili foreste di abeti e di faggi giganteschi coprivano là tutto di ombre; ameni praticelli e ripiani vestiti di muschio fra i fossatelli e i filoni di pietre si arrampicavano su per le coste, mentre più al basso nereggiavano selve di castagni, che a suo tempo dovevano far rosseggiare il suolo della dolce loro manna. Quegli abeti, quei castagni due tre volte secolari, formanti intrecci e volte di verdura impenetrabili al sole, le rocce tagliate a picco, i corsi di acque limpide, componevano un insieme ora ameno ora selvaggio, ma grandioso sempre e attranente. Il Santo a quel magnifico e imponente spettacolo si senti forzare alle lacrime e, ringraziandone di cuore Dio, si inginocchio e bacio quella terra quasi per consacrarla a lui e per pigliarne possesso in suo ome.'

105. Tarani, L'Ordine vallombrosano (as in n. 75), p. 6.

106. Casini (as in n. 103), pp. 53-67. 
Assisi, another exemplar of penitence, are commonly depicted together in Vallombrosan churches. ${ }^{107}$

A home-grown saint, Giovanni Gualberto was naturally much feted in Florence, his feast day of 12 July celebrated by the whole city, the non-closure of shops a punishable offence. ${ }^{108}$ The sacra rappresentazione di S. Giovanni Gualberto was performed in the piazza in front of S. Trinita, probably at vespers on that day, as well as during the St John the Baptist parades. A very popular spectacle attended by men, women and children, the sacred drama was performed entirely by youths, ${ }^{109}$ the actors trained and prompted by a festival organiser (festaiuolo), a position held more than once by a Gianfigliazzi. ${ }^{110}$ God in Trinity was positioned above the stage on a magnificent throne surrounded by angels and flickering lights, while episodes of the saint's life were played out in a grandiose drama, with the ultimate aim of inspiring good conduct. ${ }^{111}$ Additionally, Giovanni Gualberto was commemorated throughout the year by the Compagnia del Zampillo ('Confraternity of the Spring'), which for most of the fifteenth century met at S. Trinita. ${ }^{112}$ A company of disciplinati, the Zampillo was noted for its beautiful singing. ${ }^{113}$ Its name referred at once to the wondrous spring on

107. M. A. Pavone, Iconologia francescana: Il quattrocento, Todi 1988, pp. 76-88; B. Santi, 'Pittura "minore" in S. Trinita: da Bicci di Lorenzo a Neri di Bicci', in La chiesa di Santa Trinita (as in n. 62), pp. 132-42 (142 and fig. 128).

108. A statute of the commune in 1415 ordered that: '... che fosse celebrata da tutti in perpetuo la festa di S. Giovangualberto, che cade il giorno 12 luglio, coll'obbligo di tener chiuse le botteghe, con grave multa per i trasgressori'; Richa (as in n. 102), III, p. 151; Tarani, 'Ufficiatura e devozioni' (as in n. 103), p. 33.

109. J. S. Kennard, The Italian Theatre: From its Beginning to the Close of the Seventeenth Century, 2 vols, New York 1932, I, pp. 34-37.

110. C. Guasti, Le feste di San Giovanni Batista [sic] in Firenze descritta in prose e in rima da contemporanei, Florence 1908, p. 50; Bartolomeo Masi, Ricordanze di Bartolomeo Masi calderaio fiorentino dal 1478 al 1526, ed. G. O. Corazzini, Florence 1906, p. 204.

111. Kennard (as in n. 109), I, pp. 36-44, 55-60; Sacre rappresentazioni dei secoli XIV, XV e XVI, ed. A. D’Ancona, 3 vols, Florence 1872, III, pp. 139-73.

112. 'Compagnia di S. Gio. Gualberto detta il Zampillo: L'anno 1473 si ragunava in S. Trinita'; ASF, Carte Strozziane, IIIa, 233, fol. $61^{\mathrm{r}}$.

113. On it being a compagnia di disciplina see Hatfield, 'Compagnia de' Magi' (as in n. 47), p. 127, citing Benedetto Dei, Ricordanze (Florence, Biblioteca Riccardiana MS Moreni 103, fol. $66^{\mathrm{r}}$ ). On the Zampillo's singing, Hatfield, ibid., cites a letter from Gentile de' Becchi to Clarice Orsini de' Medici, 10 
Monte Secchieta and to the 'Pozzo di S. Giovangualberto' in the sacristy of S. Trinita (Fig. 15). Feast day processions culminated in paying homage at this pozzo and drinking its miraculous water, reputed to be especially efficacious against the plague. ${ }^{114}$ Lorenzo de' Medici's brother Giuliano attended meetings of this compagnia until his death at the hands of the Pazzi conspirators in 1478, following which the Zampillo was merged with the Compagnia de' Magi, meeting thereafter at S. Marco. ${ }^{115}$ The fact that on his death in 1492 Lorenzo de' Medici's body was carried to the Compagnia del Zampillo at S. Marco, ${ }^{116}$ indicates his particular identification with St Giovanni Gualberto and the confraternity which promulgated his cult.

The special devotion of the Vallombrosan Order to the Holy Trinity began with Giovanni Gualberto, who was determined to extinguish the heresy against the Trinity inculcated by Arianism. ${ }^{117}$ Following his precepts, Vallombrosan houses dedicate every Sunday of the year to the Holy Trinity and the monks recite several times every day his trina orazione, or threefold prayer. ${ }^{118}$ The order's attachment to the triune Godhead is reflected in the very name given to the abbey of S. Trinita when it came into Vallombrosan possession in the eleventh century. ${ }^{119}$ The interior of the abbey was, and still is, liberally decorated with images of the Holy Trinity.

Feb. 1479; BNCF, Ginori-Conti, 29, 19, fol. 2. In his Cronica (as in n. 82), pp. 66-67, Benedetto Dei noted that the Zampillo took part in the processions on 25 Apr. 1459 for the entry of Pope Pius II.

114. Tarani, 'Ufficiatura e devozioni' (as in n. 103), p. 33.

115. Hatfield, 'Compagnia de' Magi' (as in n. 47), pp. 126-28. See also 'Compagnia del Zampillo: Si ragunava in S. Marco ma fin presa da frati slargarsi'; ASF, Carte Strozziane, IIIa, 233, fol. $26^{\mathrm{v}}$.

116. 'Mortto Lorenzo, a ore 7 fu portato ne la compagnia del Zampillo in Firenze in S. Marcho chon moltitudine d'huomini e di torchi, et addì 9 a ore una e sacerdoti di S. Lorenzo lo chonduxono in sagrestia d'essa loro chiesa chon 60 torchi, et otto de la casa portavano la bara.' Bartolomeo Cerretani, Storie fiorentina, ed. G. Berti, Florence 1994, p. 185.

117. 'L'uso di quella trina oratione, fu dal Santo Abbate nemico del nome hereticale, introdotto in memoria degli antichi Monaci, i quali con le predicationi, e col sangue mantennero frà i popoli dell'Oriente la Nicena fede, contro Ario biastemmatore della Trinità'; Diego De Franchi, Historia del Patriarcha S. Giovangualberto, primo Abate ed Institutore del Monastico Ordine di Vallombrosa, Florence 1640, BNCF, Magl.10.5.425, pp. 205-06. See also Tarani, 'Ufficiatura e devozioni' (as in n. 103), p. 32.

118. Tarani, 'Ufficiatura e devozioni' (as in n. 103), p. 32.

119. H. Saalman, The Church of Santa Trinita in Florence, New York 1966, pp. 4, 15. As recorded by Marco di Bartolomeo Rustichi in 1425, the exterior façade of the church was decorated with mosaics showing an adoration of the Holy Trinity by nine angelic choirs: "chon belle chapelle e nella faccia 
Returning now to the iconography of the Birmingham altarpiece, in the first place it should be borne in mind that the painting features a verdant, rural landscape. ${ }^{120}$ The plantations, woods, meadows and water in Rosselli's painting are altogether suggestive of the rural locations favoured by the Vallombrosan order. The early Vallombrosan houses were located in the countryside rather than in towns. ${ }^{121}$ Giovanni Gualberto's responsiveness to nature is reflected in the order's prayers. In a fifteenthcentury breviary from Vallombrosa, the matins prayer for the feast of St Giovanni Gualberto, still uttered today, is pregnant with water symbolism:

... I will irrigate my garden of plantations and I will water the fruit of my meadow, and behold, an abundant path has been made for me and the river of our Christ has approached the sea. ${ }^{122}$

Indeed, this line of argument might be taken further. While few early Renaissance landscapes fully represent actual places, some do make reference to particular sites. ${ }^{123}$ Rosselli showed himself to be at the forefront of a growing fashion for including topographical settings in his paintings. ${ }^{124}$ The building in the painting nestling at the water's edge, glimpsed between the heads of the Virgin and St Francis, could perhaps be intended as Vallombrosa, which was extended in the mid to late fifteenth century, receiving a large, new cloister and tower. ${ }^{125}$

dinanzi, di fuori, è lavorata d'opera musaicha'; Archivio del Seminario di Cestello Firenze, Codice Rustici (1425), fol. $35^{\mathrm{v}}$.

120. As noted above at n. 18, Rosselli's landscape is indebted to Flemish painting. Bongianni Gianfigliazzi is likely to have brought back such treasures from his time spent in Bruges. He was in Flanders and England for one year from Oct. 1461; see Arrighi, 'Gianfigliazzi, Bongianni' (as in n. 90), p. 345. He returned from a further trip there in May 1467; see M. Martelli, 'La cultura letteraria nell'età di Lorenzo', in Lorenzo the Magnificent (as in n. 48), pp. 167-176 (169).

121. See E. Micheletti, 'Prefazione', in La chiesa di Santa Trinita (as in n. 62), p. xi.

122. 'Dixi rigabo ortum meum plantationum et inebriabo prati mei fructum, et ecce factus est michi trames abundans et fluvius nostri Christi propinquavit ad mare.' Florence, Biblioteca Medicea Laurenziana MS Conventi soppressi Vallombrosa, 512, fol. $428^{\mathrm{v}}$. We are grateful to Carolinne White for pointing out that the source for this passage is Ecclesiastes 24.42-43.

123. Kent, Cosimo de' Medici (as in n. 11), p. 256; R. J. M. Olson, The Florentine Tondo, Oxford and New York 2000, p. 175.

124. For example, the background of his Vocation of St Philip Benizzi, Chiostro dei Voti, Santissima Annunziata, c. 1475; and in his Display of the Miraculous Relic, Sant'Ambrogio, 1484-86. For the former see Gabrielli (as in n. 1), pp. 147-49, cat. 32; for the latter, ibid., pp. 185-94, cat. 57.

125. C. Caneva, Museo d'arte sacra dell 'Abbazia di Vallombrosa, Florence 2007, p. 185. 
Rosselli's depiction of Sts Benedict, Jerome and Francis, too, can be read as particularly appropriate for S. Trinita since all were venerated by the Vallombrosans. The slim, golden cross which St Francis holds in his right hand recalls the order's veneration of the Holy Cross. ${ }^{126}$ The original pale grey of his habit was for a long time obliterated by an over-layer of coarse grey-black oil paint. ${ }^{127}$ The seventeenth-century Vallombrosan historian Diego De Franchi makes much of the fact that St Francis chose pale grey for his friars' habits after the example of Giovanni Gualberto, and that until around the year 1500, Franciscan and Vallombrosan dress was indistinguishable apart from the knotted cord. ${ }^{128}$ He takes care to mention that on Francis's famous pilgrimage to Mount Alverna in 1224, encountering great floods at Vallombrosa, the then Vallombrosan abbot gave the traveller his own habit to change into, which Francis continued to wear on his onward journey. ${ }^{129}$ In De Franchi's opinion, the special devotion of the Vallombrosan order to St Francis can be traced back to that meeting and act of charity. ${ }^{130}$

Like St Francis, whose importance for the Gianfigliazzi has already been noted, St Jerome can also be linked to the family, for their name appears on the roll call of the Congregazione degli eremiti di S. Girolamo mentioned earlier, ${ }^{131}$ evidencing the family's participation in the growing cult. ${ }^{132}$ The representation of all three saints is

126. See above at n. 103.

127. Barber Institute curatorial file, 'Treatment Report', p. 3.

128. De Franchi (as in n. 117), p. 190.

129. Ibid., pp. 189-90.

130. Following a survey of the colours worn by monks in traditional monastic houses (black, white or grey), De Franchi turns to the two new mendicant orders: '...à quella fù dal Padre san Domenico data la diuisa distinta da amebedue i contrarij colori, bianco, e nero: à questa dal Padre san Francesco si diede il bigio Vallombrosano, come meno artifitiato. Dalla qual promiscua differenza di veste, accomunata à $\mathrm{i}$ Francescani, credo che nascesse la special deuotione dell'Ordine di Vallombrosa verso il serafico san Francesco fino dai principij della santità di lui. Imperò che ne i Messali dell'Ordine scritti à quei tempi si hà partitamente distesa la Messa del serafico Santo, senza memoria alcuna dell'altro celebre Patrarcha di lui coetaneo.' Ibid., p. 313.

131. See above at n. 31 .

132. Ridderbos (as in n. 28), p. 77. When in 1441 St Antoninus established the 12 Buonomini di S. Martino, its committee members were chosen by him from the Compagnia di S. Girolamo; ibid., p. 81. Bongianni Gianfigliazzi, his brother Gherardo and his son Jacopo all served as Buonomini; see Bongianni's Libro di ricordi in ABSM MS 2.1.0.1, fols $14^{\mathrm{r}}$ and passim; ASF, Raccolta Sebregondi, 2573/A. 
thus congruent not only with the theme of asceticism and penitence practised by the Vallombrosans but also with the pre-existing programme of the Gianfigliazzi St Benedict chapel. This was decorated with frescoes of the late fourteenth century, fragments of which have survived. ${ }^{133}$ On the nave wall above the chapel entrance is $S t$ Benedict in Penitence in the Wilderness (Fig. 16). ${ }^{134}$ In the fifteenth century, the rest of the chapel most likely contained a life cycle of St Benedict, ${ }^{135}$ depicting some of the episodes that are still to be seen, for example, in Spinello Aretino's extensive series in the sacristy of S. Miniato al Monte. ${ }^{136}$ In the reveal of the entrance arch are remnants of half figures in medallions of the twelve apostles, while a now empty tomb niche on the inside of the east wall is decorated with an image of Bishop Maximinus officiating at the Communion of St Mary Magdalene (Fig. 17). This bears the inscription: 'Do not despair, you who are accustomed to sin, and by means of my example prepare yourselves in heart and repair yourselves for God ${ }^{137}$ Overcoming the sins of the flesh is likewise a subject of the St Benedict in Penitence in the Wilderness. On the right of

133. The frescoes were uncovered in 1889; Paatz (as in n. 60), v, pp. 289-90. M. Boskovits, Pittura fiorentina alla vigilia del Rinascimento, Florence 1975, pp. 285-87, attributed them to either Cenni di Francesco di Ser Cenni or Spinello Aretino. Scholars are not agreed on the subject matter of the tomb niche fresco: the Paatzes read it as St Zosimus officiating at the Communion to Saint Mary of Egypt; ibid., p. 290. They were followed by E. Borsook and J. Offerhaus, Francesco Sassetti and Ghirlandaio at Santa Trinita, Florence: History and Legend in a Renaissance Chapel, Doornspijk 1981, p. 189; and by Santi, 'Pittura "minore" in S. Trinita' (as in n. 107), p. 133. Strehlke (as in n. 69), p. 27, however, identifies the female saint as Mary Magdalene.

134. On attribution and date see Boskovits (as in n. 133), p. 287.

135. In 1415 Piera degli Scali referred to the St Benedict and St Lucy chapels (Gianfigliazzi and Strozzi, respectively), including their istorie, as exemplars for the standard of beauty expected in the still then unfinished Scali Chapel: '...habeat seu contineat in se altare tabulam pitturas graticolas et omnia et singula aliaque et qualia habent seu tenens ad presens una ex dictiis alis duabus cappellis exceptis quoad pictam tam dicte cappelle quam tabule dicti altaris istoriis que non sint nec esse debeant illem, et que sunt in aliqua dictarum aliarum duarum cappellarum se sint et esse debeant istorie sancti Bartolomei sint tamen et esse debeant dicta istoria picta et ornate pulchre et perfecte bonis et pulchris figuris et pictoris equalibus vel melioribus et pulchrioribus illisque sunt in dictis aliis duabus cappellis...' ASF, Conv. soppr. 224,22 , fols $371^{\mathrm{r}}-72^{\mathrm{r}}$.

136. T. J. Loughman, Spinello Aretino, Benedetto Alberti and the Olivetans: Late Trecento Patronage at San Miniato al Monte, Michigan 2003, pp. 245-325.

137. 'Ne desperetis vos qui peccare soletis examploque meo vos reparate (corde parate) Deo'. See n. 131. 
the fresco, Benedict, living a solitary hermit life in the desert, cures himself of carnal lust by rolling his naked body in briers and brambles. ${ }^{138}$ The left-hand side of the same image shows the saint in solitary contemplation at the convent near Subiaco-the monks of which, however, found his rule too rigorous, ${ }^{139}$ which was exactly the reason it was adopted by Giovanni Gualberto for his new order.

\section{Part III: Monna Tommasa Gianfigliazzi}

At this period, when Bongianni Gianfigliazzi's career in support of Lorenzo de' Medici was undergoing a meteoric rise and the 'old' Gianfigliazzi palace was, finally, back in Gianfigliazzi hands, the moment would have been apposite for the reinvigorated clan to consider the commissioning of a new altarpiece for its ancestral chapel.

The suggestion of the inclusion of St Francis may well have emanated from Monna Tommasa Gianfigliazzi, who was now the main owner of the palace and whose line of the family, the Giannozzo heirs, had celebrated the feast of St Francis in the chapel for most of the fifteenth century. Tommasa cannot, however, be regarded as the definitive patron of the altarpiece. First, she died in 1479, several years before the painting must have been completed. For the final years of her life Tommasa and her two daughters, Suore Marietta and Perpetua, committed themselves to the Benedictine convent of S. Maria Annunziata delle Murate. ${ }^{140}$ On entering the convent, Tommasa let her portion of the Gianfigliazzi palace to the son of her late husband's cousin, Bertoldo di Bertoldo di Antonio di Rinaldo. Following her death, this part of the palace was ceded to the convent, Bertoldo reaching an agreement with the nuns that he or his heirs could stay in the property. ${ }^{141}$ Therefore, in any negotiations regarding an

138. Jacobus de Voragine (as in n. 28), I, p. 310; tr. Granger Ryan, I, p. 187.

139. Ibid.

140. This convent was named as a beneficiary in Bongianni Gianfigliazzi's will of 1464; ASF, Not. antecos. 21063 (Nastagio Vespucci), insert 4, fols 55-58 (48 ). BNCF MS Passerini 156, insert 8, fol. $1^{\mathrm{v}}$, confirms Monna Tommasa's entry to it, 'si commesse già nelle Murate' (see Fig. 13. She joined her two daughters there; see K. J. P. Lowe, Nuns' Chronicles and Convent Culture in Renaissance and CounterReformation Italy, Cambridge 2003, p. 267. She ended her days there on 19 Jan. 1479; ABSM MS 4.1.1.0.2 'Contratti della casa Gianfigliazzi', insert 4, 'Dal 1469 al 1480'.

141. They would continue to make the same payments to the convent of 700 florins. See the three documents dated 3 Jan. 1469, 19 Jan. 1479. and 29 Mar. 1480; ABSM MS 4.1.1.0.2 'Contratti della casa 
altarpiece for the family chapel, it would probably have been Bertoldo who would have liaised between parties. In any case, with male members of the family living in the vicinity, it would have fallen to them to draw up a contract with the artist and oversee the work. ${ }^{142}$ One imagines that with several different lines of the family all using the chapel, the decision to commission a new altarpiece would have been a clan agreement.

There are, nonetheless, considerations which tend to indicate that, if Rosselli's Adoration of the Child Jesus was indeed painted for the Gianfigliazzi chapel, then Tommasa may have been closely and personally involved in the family discussions which preceded its commission. Once installed or, rather, re-installed into the old Gianfigliazzi palace at the end of the 1460s, Tommasa may have felt it incumbent upon her to redress in some measure the dishonour done to her deceased husband Baldassare di Francesco di Rinaldo Gianfigliazzi. A new altarpiece to replace that of Cenni di Francesco in the family chapel could have provided such an opportunity. Let us for the moment hypothetically suppose this to be the case and turn once more to the iconography of Rosselli's painting (Fig. 1). The Virgin Mary and the circle of saints beside her gaze down adoringly at the infant Christ lying in their midst, with the notable exception of the second Magus Balthazar, who contrastingly lifts his eyes in an upward direction. In accordance with fifteenth-century religious practice, the faithful prayed to God in heaven through power-laden objects - through the host, a holy relic or a religious image ${ }^{143}$ If prayers were to be said for the soul of Baldassare Gianfigliazzi, these would be transmitted through his name saint in a chain of intercession. For example, Filippino Lippi's Virgin and Child with Sts Jerome and Dominic (Fig. 4), which has already been cited as a possible influence on Rosselli's altarpiece, includes St Dominic as the name saint of Domenico di Filippo di Vanni Rucellai, who died in $1484 .{ }^{144}$ In the painting, St Balthazar's eyes, turned heavenward,

Gianfigliazzi', insert 4, 'Dal 1469 al 1480'. Benedictine nuns enjoyed the greatest latitude in property rights, especially the Observant branch of Le Murate; se S. T. Strocchia, Nuns and Nunneries in Renaissance Florence, Baltimore MD and London 2009, p. 85.

142. C. E. King, Renaissance Women Patrons: Wives and Widows in Italy c.1300-1550, Manchester 1998, pp. 99-100.

143. R. C. Trexler, 'Florentine Religious Experience: The Sacred Image', Studies in the Renaissance, XIX, 1972, pp. 7-41 (9).

144. Dunkerton (as in n. 17), pp. 338-39. 
may be seen to be upwardly directing the family's prayers for the dead. ${ }^{145}$ If this interpretation is correct, it is suggested that the saint's gesture may, then, obliquely refer to his namesake Baldassare Gianfigliazzi, who had lived in the palazzo next door to the church and whose body, but for his exile, would have been interred in its chapel of St Benedict. Commissioning an altarpiece which included St Balthazar would have been a fitting gesture on Monna Tommasa's part, the nearest approximation to posthumously 'restoring' her husband to his rightful final resting place. The Magi are not always depicted as saints in Florentine images of this period; their haloes in Rosselli's painting, therefore, suggest compliance with a specific request from his clients. ${ }^{146}$ Devotion to the second of the three Magi is found elsewhere in Florence, practised for example by the nuns at the nearby convent of S. Baldassare at Coverciano on the outskirts of the city. ${ }^{147}$ Closer to home, Florence's earliest extant monument to the Magi had been commissioned in honour of his name saint by Baldassare Ubriachi: completed at S. Maria Novella in 1378, this relief shows its patron kneeling beneath the saint's protecting arm as, together with the other two Magi, they approach the Virgin and Child (Fig. 18). ${ }^{148}$ Cosimo Rosselli was acquainted with the Ubriachi Chapel, since he had painted its altarpiece over a decade earlier. ${ }^{149}$ Thus, if the hypothesis put forward here is correct, the Gianfigliazzi family

145. Burckhardt (as in n. 26), p. 92, notes the significance of saints' costume, pose, placing, as well as the positioning of their heads and direction of their gaze (upwards or downwards). A connection can be made here with the saints' upturned faces and supplications on behalf of plague victims in contemporary Umbrian gonfaloni; see E. Schröter, 'Raffaels Madonna di Foligno. Ein Pestbild?', Zeitschrift für Kunstgeschichte, L, 1987, pp. 46-87 (62-66).

146. For Adoration of the Magi paintings in which the Magi do not bear haloes see, e.g., Domenico Veneziano, after 1438/9-41, Berlin, Gemäldegalerie, Staatliche Museen (inv. 95A); Filippo Lippi, c. 1445, Washington DC, National Gallery (Samuel H. Kress Collection, 1952.2.2); Botticelli, c. 1470-75, London, National Gallery (inv. 1033); and Rosselli's Adoration of the Magi, probably painted for the Compagnia dei Magi, at S. Marco, Florence, Galleria degli Uffizi (inv. 1890, 494), for which see Gabrielli (as in n. 1), pp. 155-57, cat. 37. Conversely, the Magi are shown with haloes in Gentile da Fabriano's altarpiece completed for Palla Strozzi in 1423, at that time installed in the Sacristy of S. Trinita; Florence, Galleria degli Uffizi (inv. 1890, 494).

147. 'La regola delle monache di S. Baldassare', BNCF, Conv. soppr., C.8, 1990.

148. R. C. Trexler, 'The Magi Enter Florence: The Ubriachi of Florence and Venice', Studies in Medieval and Renaissance History, I, 1978, pp. 129-217 (138).

149. Cosimo Rosselli, Madonna and Child Enthroned with Four Angels and Saints, now in the Staatliche Museen, Berlin; Padoa Rizzo, 'Work for Lay Confraternities' (as in n. 58), p. 63. 
were following local precedent, not only in showing deference to the cult of the three Magi, but also in singling out St Balthazar for particular veneration, as the name saint of their departed family member.

There is, finally, a postscript which may serve to reinforce the proposition that Cosimo Rosselli's Adoration of the Child Jesus resulted from an initiative instigated by Monna Tommasa Gianfigliazzi and put into action by her relations. A strikingly similar Adoration of the Child, today on display in S. Francesco in Fiesole (Fig. 19), was originally commissioned for the same convent of S. Maria Annunziata delle Murate in which Tommasa ended her days. The abbess of the Murate, writing about a century after the commission of the painting in c. 1495, attributed it to Lorenzo di Credi (c. 1459-1537) and recorded it as positioned in the nun's oratory. ${ }^{150}$ The work is now attributed to the 'Master of the Epiphany of Fiesole'. ${ }^{151}$ As in Rosselli's painting, this later altarpiece shows the Virgin adoring the Christ Child, God the Father and the Holy Ghost, angels and a distant landscape. Again it features the three Magi in the foreground, even if in this version they are not depicted as saints; and also St Francis, although he is now on the Virgin's right side and no longer holds a cross. St Benedict and St Jerome, replacing St Paul and St John the Baptist, complete the circle. ${ }^{152}$ Bearing in mind the close similarity in iconography, the proximity in dates and the presence at the Murate of the Gianfigliazzi nuns, it is suggested that the Gianfigliazzi

150. 'Nell'oratorio del Veronica la tavola del Santissimo Presepio la dono Niccolò Capponi che la fece fare à poso à un eccellente Pittore detto Lorenzo Credi per sua particulare devotione'; Suora Giustina Niccolini, 'Chronaca del monasterio delle Murate 1390 al 1587', BCNF MS II.II.509, fol. 174ำ The identification of the painting described here with that at Fiesole is demonstrated by Lowe, Nuns' Chronicles (as in n. 140), pp. 347-52. Niccolò Capponi, named by the abbess as the patron of the altarpiece, was possibly Niccolò di Piero Capponi (1473-1529); F. W. Kent, Household and Lineage in Renaissance Florence: The Family Life of the Capponi, Ginori and Rucellai, Princeton, NJ 1977, p. 304. He was presumably a relation of Bartolommeo Capponi, who was made abbot of S. Trinita in June 1497; Richa (as in n. 102), III, p. 179.

151. For this attribution and the dating of the painting (Galleria degli Uffizi, inv. 1890 3935) to c. 1495 see A. Padoa Rizzo, 'L'altare della Compagnia dei tessitori in S. Marco a Firenze: dalla cerchia di Cosimo Rosselli al Cigoli', Antichita viva, XXVIII, 1989, pp. 17-24 (20). Similarities are noted in its current label at S. Francesco, Fiesole, between the Murate altarpiece and the style of Jacopo del Sellaio, who worked in Cosimo Rosselli's ambit; Budny and Dabel (as in n. 4), p. 33; Gabrielli (as in n. 1), pp. 208, 214.

152. It may be relevant that the abbess's chronicle lists relics of St John the Baptist and St Paul, amongst others, as belonging to the Murate; Giustina Niccolini (as in n. 150), fol. 178 ${ }^{\mathrm{r}}$. 
may have played a so-far unnoticed part in the inception also of this later altarpiece. Further research may conceivably unearth material which sheds light on the matter.

Future research may, too, confirm or invalidate the present hypothesis regarding patron and original location of the work which has been the main focus of this article, Cosimo Rosselli's Adoration of the Child Jesus; conversely these may never be known with certainty. To conclude, however, on a less equivocal note, the painting has been contextualised in this paper to demonstrate its incorporation of both traditional typologies and recent iconographic and compositional innovations in Florence. For a long, indeterminate period of time the altarpiece has been divorced from its original setting. For the last half-century it has remained a large, luminous curiosity at the Barber Institute of Fine Arts, representative of the apogee of the Florentine Renaissance, yet at the same time the work of a largely-forgotten artist of reputedly unremarkable ability. According to traditional narratives of art history which have incorporated and consolidated the Vasarian model, Rosselli's style was soon to be swiftly eclipsed with the onset of the High Renaissance. ${ }^{153}$ This may in part account for the limited scholarly attention that has been paid to the Birmingham altarpiece. Painted - it is suggested - contemporaneously with the Cappella del Miracolo at S. Ambrogio, ${ }^{154}$ the altarpiece exemplifies Rosselli at the peak of his activity and keeping pace with the very latest artistic innovations. The Adoration of the Child Jesus serves

153. For Vasari's entry on Cosimo Rosselli see above, n. 2. P. and L. Murray, The Art of the Renaissance, London 1963, p. 267, characterised the High Renaissance (usually dated to roughly between 1500 and 1530) thus: 'Bramante died in 1514, Leonardo da Vinci in 1519, and Raphael in 1520; with them the Renaissance passed into history, for it is a watershed which divides Giovanni Bellini, Piero della Francesca, and even Giorgione from Michelangelo and Tintoretto. Perhaps only Titian was able to cross it ...'. More recently M. Wundram, The Oxford Dictionary of Art (Grove Art Online resource, 2008), s.v. 'Renaissance', writes: 'It is generally accepted that artists of the High Renaissance developed more monumental forms and created unified and harmonious compositions that reject the decorative details of 15th-century art'. J. Burke, 'Inventing the High Renaissance from Winkelmann to Wikipedia: An Introductory Essay', Rethinking the High Renaissance: Culture and the Visual Arts in Early SixteenthCentury Rome, ed. eadem, Farnham 2012, pp. 1-23 (2), cites this passage and alerts us to potential misconceptions which can arise from an uncritical acceptance of such deeply-embedded, monolithic and implicitly value-laden terminology. The papers contained in Burke's volume demonstrate that High Renaissance visual culture should be understood as complex, eclectic and heterogeneous.

154. See above at n. 54. 
as a register of the ferment of theological and representational ideas being rehearsed in Florence at this significant moment in the history of western art.

\section{Birmingham City University}

\section{List of Illustrations}

Fig. 1: Cosimo Rosselli, The Adoration of the Child Jesus, c.1485, tempera on wood, 177.8 x $147.3 \mathrm{~cm}$, University of Birmingham, Barber Institute of Fine Arts (@) Barber Institute of Fine Arts, Birmingham)

Fig. 2: Filippo Lippi, The Adoration of the Infant Jesus, late 1450s, tempera on poplar, 127 x $116 \mathrm{~cm}$, Berlin, Gemäldegalerie, Staatliche Museen (@ Photograph: Warburg Institute)

Fig. 3: Andrea della Robbia, The Incarnation, c.1479-80, glazed terracotta relief, 240 x $180 \mathrm{~cm}$, La Verna, Chiesa Maggiore (@) 2015 Photo Scala, Florence)

Fig. 4: Filippino Lippi, Virgin and Child with Saints Jerome and Dominic, c. 1485, oil and tempera on poplar, $203.2 \times 186.1 \mathrm{~cm}$, National Gallery, London (@ National Gallery, London)

Fig. 5: Leonardo da Vinci, Adoration of the Magi, 1481-2, oil on wood, 246 x $243 \mathrm{~cm}$, Uffizi Galleries, Florence (@2015 Photo Scala, Florence, courtesy Ministero Beni e Att. Culturali)

Fig. 6: Nicolas Froment, Mary in the Burning Bush, central panel, 1476, Aix-enProvence, Cathedral (@ Erich Lessing)

Fig. 7: Cosimo Rosselli, The Adoration of the Child Jesus, detail of Fig. 1 showing the Burning Bush and on the hill behind, a scene identified here as the annunciation to Joachim of the Immaculate Conception (ㅇ Barber Institute of Fine Arts, Birmingham)

Fig. 8: Giotto, Dream of Joachim, c.1305, Arena Chapel, Padua (@ 2015 Photo Scala, Florence)

Fig. 9: Ground plan of S. Trinita, Florence, from W. And E. Paatz, Die Kirchen von Florenz, V, Frankfurt 1953, p.276

Fig. 10: Map of area around Santa Trinita (courtesy of B. B. Preyer, 'Around and in the Gianfigliazzi Palace in Florence: Developments on Lungarno Corsini in the fifteenth and sixteenth centuries', Mitteilungen des Kunsthistorischen Institutes in Florenz, XXXXVIII, 2004, pp. 55-104 [56])

Fig. 11: Cenni di Francesco di Ser Cenni, Polyptych with Coronation of the Virgin and Saints, c.1390s 355.8 x 233 cm, Malibu, J. Paul Getty Museum (@ J. Paul Getty Museum, Los Angeles) 
Fig. 12: Family tree, Gianfigliazzi clan (detail), BNCF, Collezione genealogica Passerini, MS 156, insert no. 8, fol. 1v, showing Giannozzo di Stoldo and Bongianni di Bongianni (1418-84) (@ Biblioteca Nazionale Centrale di Firenze, Florence)

Fig. 13: Family tree, Gianfigliazzi clan (detail), BNCF, Collezione genealogica Passerini, MS 156, insert no. 8, fol. 1v, showing the line of Messer Rinaldo Gianfigliazzi (1355-1425), including the union of Baldassare di Francesco and Tommassa di Piero di Stoldo (circled) (@ Biblioteca Nazionale Centrale di Firenze, Florence)

Fig. 14: The 'old' Gianfigliazzi palace, adjoining church of S. Trinita (Photo: authors)

Fig. 15: Florence, S. Trinita, sacristy, lavabo of S. Giovanni Gualberto, fed by water from the Pozzo di S. Giovangualberto just outside the church (@) Soprintendenza ai Beni Artistici, Florence)

Fig. 16: Cenni di Francesco, Saint Benedict in Penitence in the Wilderness, 1390s, fresco, and coat of arms of the Gianifigliazzi family, Saint Benedict Chapel, S. Trinita, Florence (@ Soprintendenza ai Beni Artistici, Florence)

Fig. 17: Cenni di Francesco, Bishop Maximinus Officiating at the Communion of Mary Magdalene, 1390s, fresco, Saint Benedict Chapel, S. Trinita, Florence (C) Soprintendenza ai Beni Artistici, Florence)

Fig. 18: Relief with the Ubriachi arms and the Adoration of the Magi, centred on St Baldassare with the patron, Baldassare Ubriachi. Florence, S. Maria Novella, chiostro grande, architrave above the Cappella del Nocentino (@ Alinari SPA, Florence)

Fig. 19: Attr. 'Master of the Epiphany of Fiesole', The Adoration of the Child with the three Magi and Saints Francis, John the Baptist and Paul, c.1495, now in San Francesco, Fiesole, formerly in Convent of S. Maria Annunziata delle Murate (C) Soprintendenza ai Beni Artistici, Florence) 